Research Article

\title{
Characteristic Features of the Evolution of a Meiyu Frontal Rainstorm with Doppler Radar Data Assimilation
}

\author{
Hongli Li $\mathbb{D}^{1,2,3}$ Yang Hu, ${ }^{1}$ Zhimin $\mathrm{Zhou}^{1}{ }^{1}$ Juxiang Peng, ${ }^{1}$ and Xiangde $\mathrm{Xu}{ }^{3}$ \\ ${ }^{1}$ Hubei Key Laboratory for Heavy Rain Monitoring and Warning Research, Institute of Heavy Rain, \\ China Meteorological Administration, Wuhan 430205, China \\ ${ }^{2}$ Nanjing University of Information Science and Technology, Nanjing 210044, China \\ ${ }^{3}$ State Key Laboratory of Severe Weather, Chinese Academy of Meteorological Sciences, Beijing 100081, China \\ Correspondence should be addressed to Hongli Li; lihongli@whihr.com.cn
}

Received 27 June 2018; Accepted 27 September 2018; Published 23 October 2018

Academic Editor: Mario M. Miglietta

Copyright (C) 2018 Hongli Li et al. This is an open access article distributed under the Creative Commons Attribution License, which permits unrestricted use, distribution, and reproduction in any medium, provided the original work is properly cited.

\begin{abstract}
During the Meiyu period, floods are prone to occur in the middle and lower reaches of the Yangtze River because of the highly concentrated and heavy rainfall, which caused huge life and economic losses. Based on numerical simulation by assimilating Doppler radar, radiosonde, and surface meteorological observations, the evolution mechanism for the initiation, development, and decaying of a Meiyu frontal rainstorm that occurred from 4th to 5th July 2014 is analyzed. Results show that the numerical experiment can well reproduce the temporal variability of heavy precipitation and successfully simulate accumulative precipitation and its evolution over the key rainstorm area. The simulated "rainbelt training" is consistent with observed "echo training" on both spatial structure and temporal evolution. The convective cells in the mesoscale convective belt propagated from southwest to northeast across the key rainstorm area, leading to large accumulative precipitation in this area. There existed convective instability in lower levels above the key rainstorm area, while strong ascending motion developed during the rainstorm process. Combined with abundant water vapor supply, the above condition was favorable for the formation and development of heavy rainstorm. The low-level jet (LLJ) provided sufficient energy for the rainstorm system, and the low-level convergence intensified, which was important for the maintenance of precipitation system and its eventual intensification to rainstorm. At its mature stage, the rainstorm system demonstrated vertically tilted structure with strong ascending motion in the key rainstorm area, which was favorable for the occurrence of rainstorm. In the decaying stage, unstable energy decreased and the rainstorm no longer had sufficient energy to sustain. The rapid weakening of LLJ resulted in smaller energy supply to the convective system, and the stratification tended to be stable in the middle and lower levels. The ascending motion weakened correspondingly, which made it hard for the convective system to maintain.
\end{abstract}

\section{Introduction}

When the East Asian summer monsoon advances northward from mid-June to early July of each year, there often exists a period of continuous rainy weather in the Jianghuai valley between 28 and $34^{\circ} \mathrm{N}$ east of Yichang in China. Since this is the plum season, precipitation during this period is called "Meiyu" "Baiu" in Japan and "Changma" in South Korea). The Meiyu rain belt extends eastward by thousands of kilometers from the Yangtze River Basin in China to Japan [1-3]. During the Meiyu period, floods are prone to occur in the middle and lower reaches of the Yangtze River due to the highly concentrated and heavy rainfall. The serious floods occurred in 1954, 1991, 1998, 1999, 2003, and 2016 caused huge economic losses [4]. Moisture transport by the southwesterly flow along the western rim of the North Pacific Subtropical High (NPSH) feeds the rainband $[5,6]$. The Meiyu-Baiurainband can be identified by sharp gradients of specific humidity and equivalent potential temperature [7] and a horizontal wind shear line [5]. Unlike moisture, the low-level temperature gradient is weak over China and modest around Japan. The Meiyu front is different from the traditional warm/cold front between warm and cold air masses. Despite its importance and socioeconomic 
impacts, the mechanism and characteristic of the Meiyu-Baiu rainstorm are poorly understood.

Meiyu as a weather phenomenon on meso-synoptic scales has been studied extensively. Many studies have investigated Meiyu precipitation from various perspectives like the physical mechanism for synoptic scale Meiyu frontal rainstorm [8], changes in the Meiyu system under global warming [9], uncertainties in the forecast of mesoscale convective systems that trigger Meiyu rainstorm [10], impacts of urbanization on Meiyu precipitation [11], and the merge of convective clouds during the rainstorm [12]. TRMM observations have also been analyzed to explore features of clouds [13] and spatial and temporal characteristics of Meiyu precipitation [14-16]. Sample and Xie [17] investigated the large-scale features and environmental forcing for the Meiyu rainbelt based on reanalysis products and suggested that the westerly jet stream is the major reason for the formation of Meiyu rainbelt. Sato et al. [18] analyzed the impact of the Kuroshio Current on mesoscale convective systems in the Meiyu front area and found that the intensified evaporation in the Kuroshio Current leads to increases in the moisture content of the air masses in the Meiyu front area, which is favorable for the maintenance of convective instability in the lower troposphere near the Meiyu front. The results of subkilometer simulation of a torrential-rain-producing mesoscale convective system in Meiyu season show that the model could reproduce the evolution of the dissipating mesoscale convective system (MCS) [19]. Based on numerical simulations, Shen et al. [20] studied the relationship between Meiyu rainstorm and mesoscale vortex disturbance originated from the planetary boundary layer (PBL). Nagata and Ogura [21] analyzed the interaction between rainstorm and low-level jet during the Meiyu season in Japan. The above studies are conducted using reanalysis products, real-time observations, and numerical simulations that can realistically reproduce the observations. The physical understanding of internal convective feedback and external large-scale environment that leads to Meiyu frontal rainstorms may be identified through such methods.

To better understand the characteristics and mechanism of Meiyu frontal rainstorms, there is a need to carry out numerical simulation with high-resolution observed data assimilation. The present study investigates the characteristics and mechanism of a Meiyu frontal rainstorm occurred in the Yangtze River Basin with the local analysis and prediction system (LAPS) as the assimilation system and the weather research and forecast (WRF) as the forecast model.

LAPS, developed and operated by the National Oceanic and Atmospheric Administration's (NOAA) Earth System Research Laboratory in Boulder, Colorado, is a mesoscale meteorological data assimilation tool that employs a suite of observations (meteorological networks, radar, satellite, soundings, and aircraft) to generate a realistic, spatially distributed, time-evolving, three-dimensional representation of atmospheric features and processes [22-26]. LAPS can serve as a tool to initialize local-scale and mesoscale weather forecast models over local to regional domains [27-30]. The Institute of Heavy Rain (IHR) has been collaborating with NOAA/ESRL (Earth System Research Laboratory) to develop the application method of LAPS in China from 2006 to 2014 [31]. The cloud fields have been improved greatly with assimilating Doppler radar data by LAPS [32]. Li and $\mathrm{Xu}$ [33] developed a correction method to correct radar reflectivity based on hourly surface rain gauge observations, which helps to improve the rainstorm forecast. Gregow et al. [34] investigated the appropriateness of four different methods to produce precipitation accumulation fields using radar data alone or combined with precipitation gauge data.

Numerical simulation of a Meiyu rainstorm using this correction method was conducted, and the heavy rainfall simulated is close to observations in terms of the location, intensity, and evolution [35]. In the present study using the results of this numerical simulation, the evolution of the Meiyu rainstorm was analyzed to explore the physical mechanism for the genesis, development, and decaying of the rainstorm system. In Section 2, we describe the numerical experiment and compare the simulated precipitation with observations. In Section 3, synoptic background and evolution characteristics of the rainstorm system are analyzed. Section 4 presents the mechanism for the initiation and development of the rainstorm system. Section 5 presents the structure characteristics of the rainstorm system at its mature stage and the mechanism for its decaying. The summary and conclusions are given in Section 6.

\section{Numerical Experiments and Comparative Analysis}

2.1. Design of Experiments. Figure 1 shows the model domain and locations of 83 Doppler radar sites, 79 radiosonde sites, and 2049 surface meteorological sites in this study. The observation variables of the operational Doppler radars in China include radar reflectivity, radial velocity, and wide spectrum. The variables of radiosonde observations include pressure, height, temperature, dew point, wind direction, and wind speed at significant levels at each site. The vertical levels include $1000 \mathrm{hPa}, 925 \mathrm{hPa}, 850 \mathrm{hPa}, 700 \mathrm{hPa}, 500 \mathrm{hPa}$, $400 \mathrm{hPa}, 300 \mathrm{hPa}, 250 \mathrm{hPa}, 200 \mathrm{hPa}, 150 \mathrm{hPa}$, and $100 \mathrm{hPa}$. The variables of surface meteorological observations include pressure, temperature, dew point, wind direction, and wind speed. Surface rain gauge observations are interpolated to $0.1 \times 0.1^{\circ}$ grid points via objective analysis and used for the verification of model simulation results. To ensure the quality of these observations, the single-radar measurements, such as radar reflectivity and radial velocity, have gone through strict quality control including calibration, nonmeteorological return filtering, and velocity dealiasing by the Severe Weather Automatically Nowcast System (SWAN) developed by China Meteorology Administration, which operates on multiple radars to yield real-time observations and products for severe weather nowcasting [36-38].

The new correction method [33] was adopted to correct three-dimensional radar reflectivity data based on hourly surface rain gauge observations. LAPS was used to assimilate the corrected radar reflectivity data, radiosonde observations, and surface meteorological observations [35]. The 


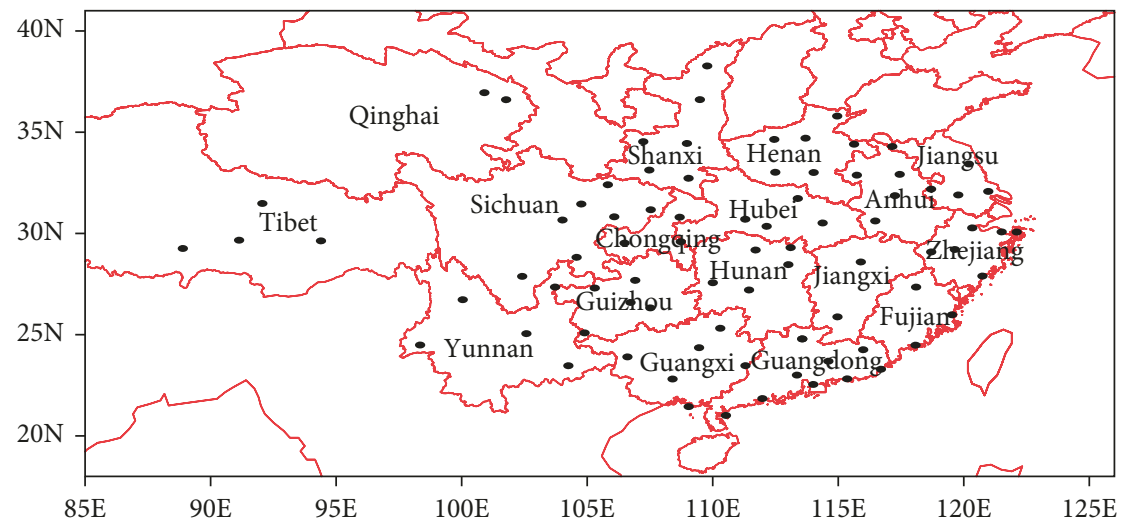

(a)

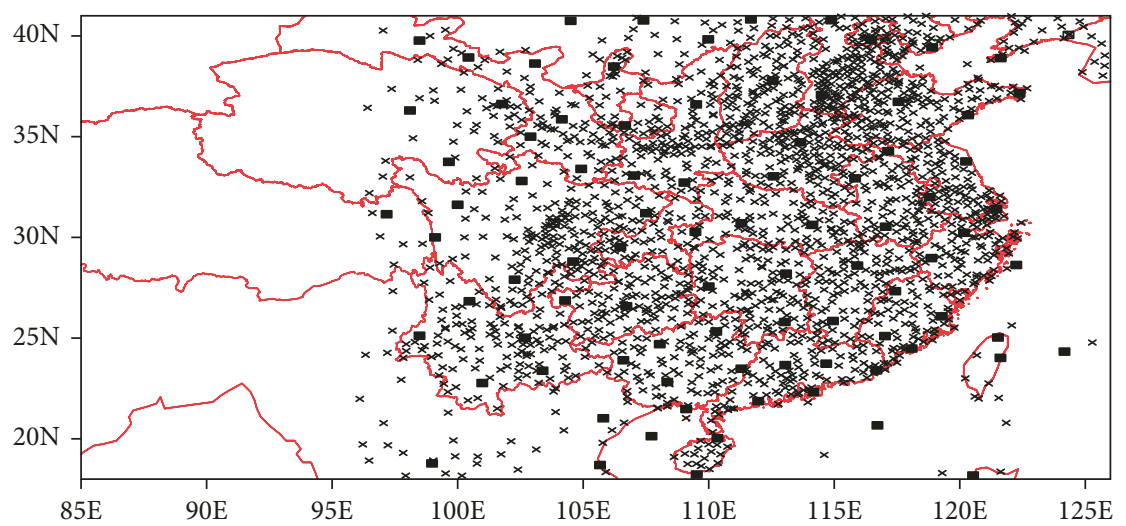

(b)

Figure 1: (a) Locations of Doppler radar sites in China (black solid circles), and (b) radiosonde (black hollow squares) and surface meteorological sites $(x)$.

mesoscale nonhydrostatic Weather Research and Forecast (WRFV3.4.1) model was integrated for 24 hours from 00 UTC 4 to 00 UTC 5 July 2014. The horizontal grid resolution is $9 \mathrm{~km}$. The model domain covers an area of $2000 \mathrm{~km} \times 2000 \mathrm{~km}$. There are 45 levels in the vertical and the model top is $50 \mathrm{hPa}$. Important physics schemes used in the present study include the WSM6 microphysics scheme, the Kain-Fritsch cumulus parameterization scheme, the YSU planetary boundary layer scheme, the Dudhia shortwave radiation scheme, and the Rapid Radiative Transfer Model longwave radiation scheme. The initial and lateral boundary field is extracted from the National Centers for Environmental Prediction (NCEP) Global data Assimilation System (GDAS) Final Operational Global Analyses $\left(1 \times 0.1^{\circ}\right)$.

2.2. Case Overview and Comparative Analysis. The observed 24-h accumulative precipitation during 00 UTC 4th to 00 UTC 5th July 2014 is presented in Figure 2(a), which shows a northeast-southwest-oriented heavy rain belt that is more than $700 \mathrm{~km}$ long and about $200 \mathrm{~km}$ wide. The rainstorm center is located in the central-southern Anhui Province (denoted by the white frame, hereafter key area of the rainstorm), which is about $150 \mathrm{~km}$ long and $100 \mathrm{~km}$ wide, extending along the east-west direction. The maximum precipitation is up to $297.9 \mathrm{~mm}$, reaching the extremely heavy rainstorm level. Numerical simulation of 24-h accumulative precipitation is consistent with observations with the maximum precipitation of $301.3 \mathrm{~mm}$, and the simulated rain belt is also oriented northeast-southwest (Figure 2(b)).

Temporal evolution of hourly precipitation in the key area of the rainstorm (Figure 3(a)) shows that the simulated precipitation evolution and magnitude both agree well with the observation. Observations indicate that there existed three heavy precipitation periods, that is, 01-08 UTC, 13-17 UTC, and 18-23 UTC, and the three peak values of precipitation occurred at 06,15 , and 21 UTC, respectively. The simulated heavy precipitation periods are during 01-11 and 13-23 and the peak values of precipitation are $7 \mathrm{~mm} \cdot \mathrm{h}^{-1}$ and $10 \mathrm{~mm} \cdot \mathrm{h}^{-1}$, respectively, which are similar to those from observations. The precipitation intensity within the key area is classified into three categories (Figures 3(b)-3(d)) to compute hourly precipitation in each category, which can represent the temporal evolution of precipitation at different magnitudes. Here, the curves of Figures $3(\mathrm{~b})-3(\mathrm{~d})$ add up to those in Figure 3(a). Figure 3(b) shows that for observed precipitation that is less than $5 \mathrm{~mm} \cdot \mathrm{h}^{-1}$, the temporal evolution of hourly precipitation is gentle with the 


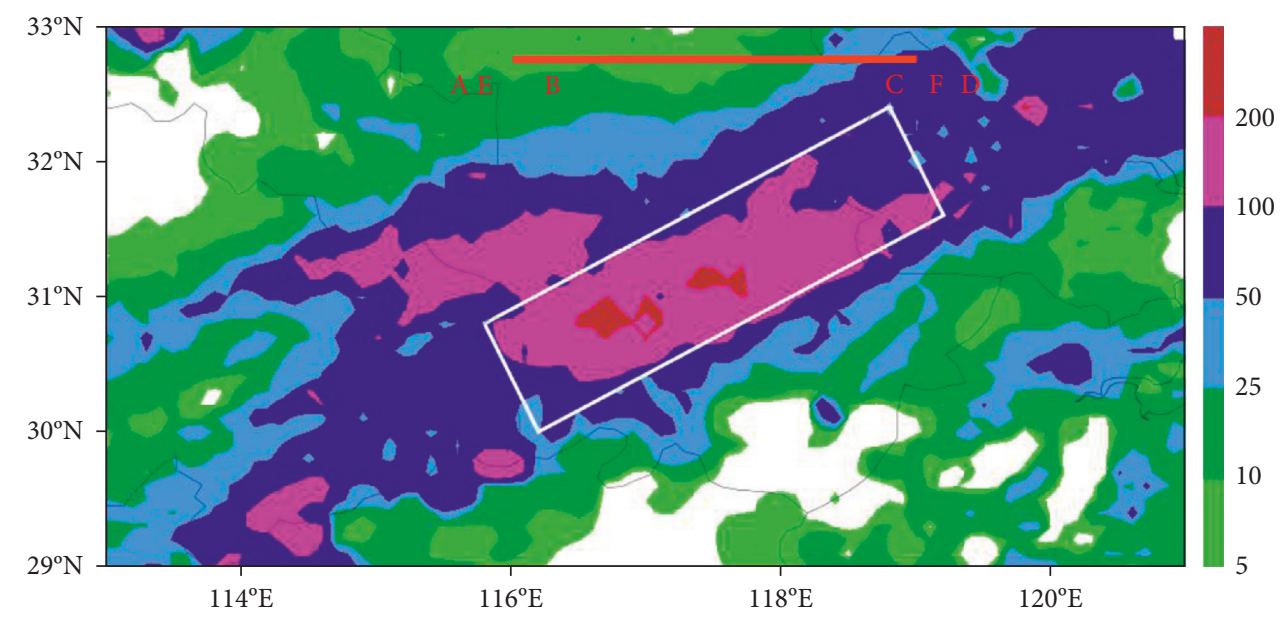

(a)

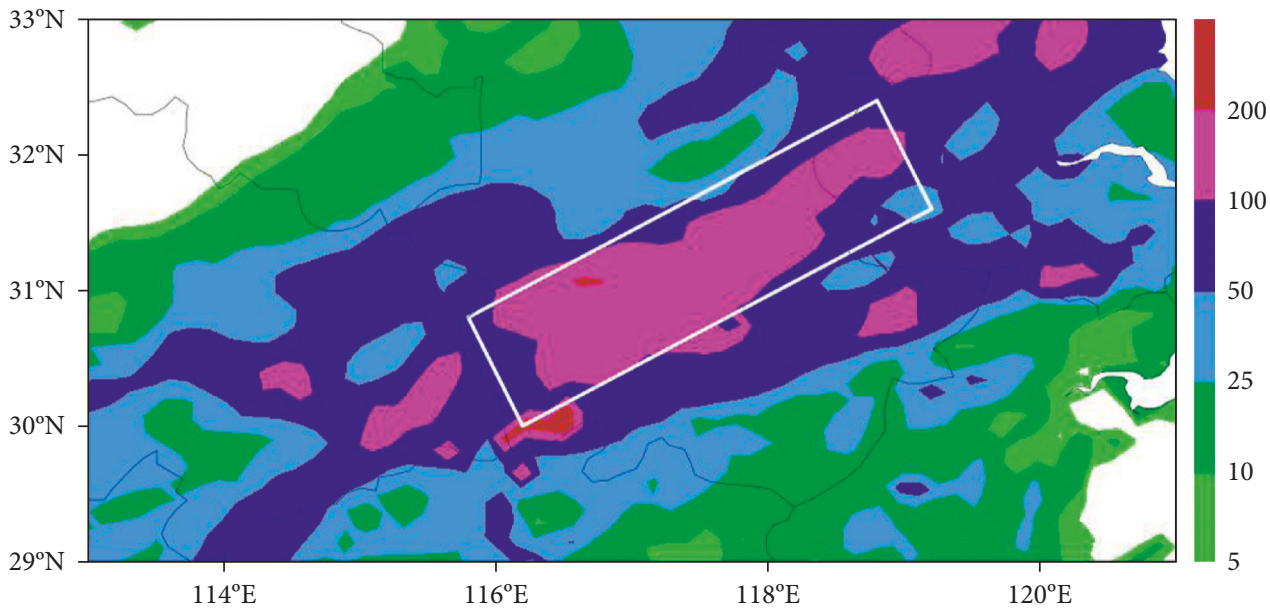

(b)

FIGURE 2: Observed (a) and simulated (b) $24 \mathrm{~h}$ accumulative precipitation during 00 UTC 4 -00 UTC 5 July 2014. The white frame indicates the key area of the rainstorm (unit: $\mathrm{mm}$ ).

magnitude less than $2 \mathrm{~mm} \cdot \mathrm{h}^{-1}$; however, the simulated hourly precipitation varies largely with a larger magnitude compared with observations. Large difference is found between the simulated and observed evolution of weak precipitation, and the model overestimates the weak precipitation. Figure 3(c) indicates that, for precipitation within the intensity range of $5-15 \mathrm{~mm} \cdot \mathrm{h}^{-1}$, their temporal evolution of hourly precipitation is consistent between observations and simulations, but the model underestimates the precipitation within this intensity range. As shown in Figure 3(d), compared with simulations of precipitation in the previous two categories, the model performs the best for simulation of precipitation that is larger than $15 \mathrm{~mm} \cdot \mathrm{h}^{-1}$, area-averaged hourly precipitation from simulation is consistent with observations in both magnitude and temporal evolution, except that the peak value is slightly biased. This result indicates that the model can well simulate the temporal evolution of heavy precipitation.

Although the numerical experiment successfully reproduces the accumulative precipitation and its temporal evolution over the key area of the rainstorm, there still exist certain deficiencies in the simulation. For example, the period during which the rainstorm maintains is slightly different from that shown by the echoes; the occurrence time of peak precipitation is also different. Despite these deficiencies, the model can well reproduce the three major periods of precipitation. The characteristics of the rainstorm and the mechanism for its evolution will be analyzed in the following sections based on the results of this numerical simulation.

\section{Synoptic Circulation and Evolution Characteristics of the Rainstorm System}

3.1. Synoptic Circulation. Heavy precipitation already started at 0000 UTC 4th July 2014 over the key area in southeastern Hubei and central-southern Anhui, which is located in front of a deep trough. In the upper level, a northeast-southwest-oriented divergence zone occurred to the west of the trough (Figure 4(a)), with the divergence larger than $15 \times 10^{-5} \mathrm{~s}^{-1}$. In the mid-troposphere, 


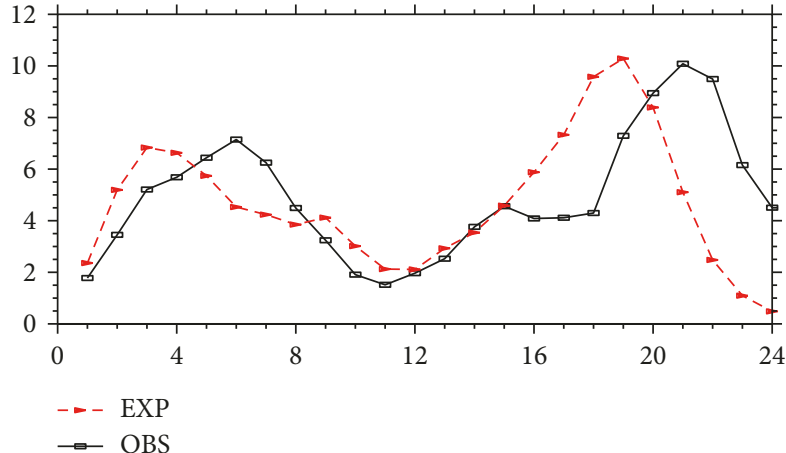

(a)

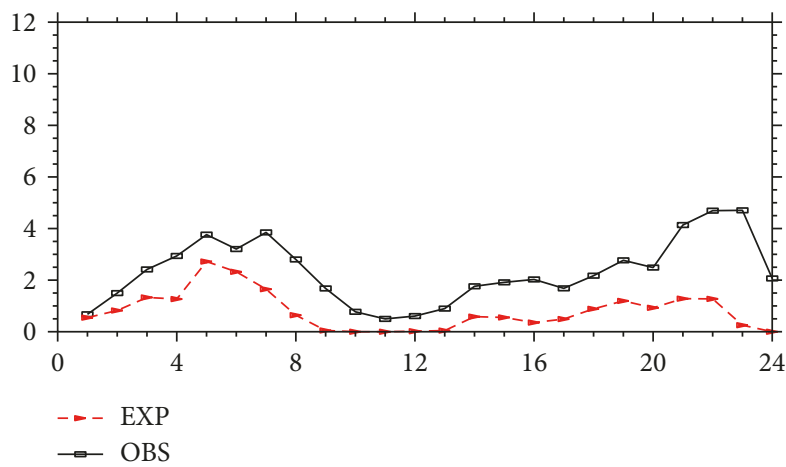

(c)

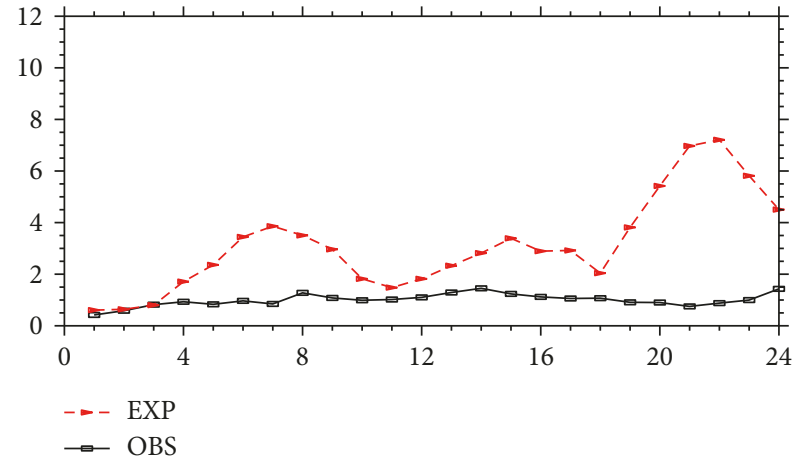

(b)

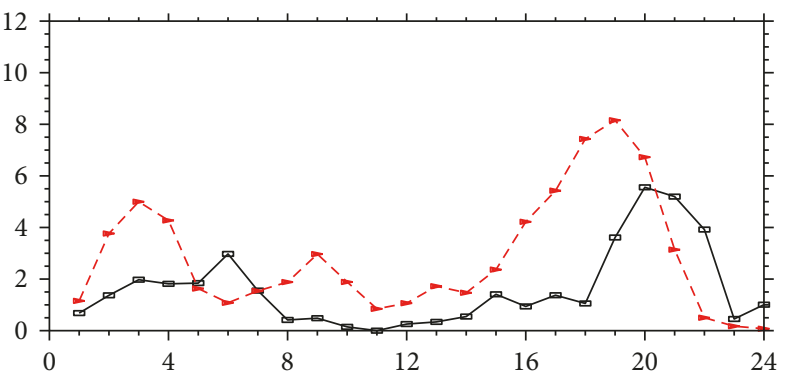

-. EXP

- OBS

(d)

Figure 3: (a) Time series of hourly average precipitation over the key rainstorm area from observations (black solid line) and simulations (red dashed line) (unit: $\mathrm{mm} \cdot \mathrm{h}^{-1}$ ); (b), (c), and (d) are the same as (a) but for the rain rates less than $5 \mathrm{~mm} \cdot \mathrm{h}^{-1}$, greater than $5 \mathrm{~mm} \cdot \mathrm{h}^{-1}$ and less than $15 \mathrm{~mm} \cdot \mathrm{h}^{-1}$, and greater than $15 \mathrm{~mm} \cdot \mathrm{h}^{-1}$, respectively. $X$ axis indicates the forecasting time from 0100 UTC 4 July to 0000 UTC 5 July 2014.

southwesterly prevailed (Figure 4(b)) with strong cold advection, indicating strong atmospheric quasigeostrophic forcing. The synoptic background in the lower troposphere demonstrated typical features of largescale background for Meiyu frontal rainstorm. The isoline of $\theta_{e}=345 \mathrm{~K}$ roughly denoted the position of the Meiyu front [16]. A quasi-west-east-extending band of dense contours of equivalent potential temperature $\theta_{\mathrm{e}}$ appeared near $30^{\circ} \mathrm{N}$ with the value of $\theta_{\mathrm{e}}$ within $337-347 \mathrm{~K}$. Significant horizontal wind shear, large humidity contrast, and relatively small temperature difference existed between the northern and southern sides of the Meiyu front. The key area of the rain storm was located within the moist band in front of the Meiyu front, where vertically integrated precipitable water was larger than $60 \mathrm{~mm}$, and a strong southwesterly jet existed in the same area (Figure 4(c)). At $850 \mathrm{hPa}$, large moisture flux appeared to the southwest of the key area of the rainstorm due to the strong water vapor transport by the southwesterly. The key area was located at the end of the strong southwest-northeast-oriented water vapor transport belt (Figure 4(d)).

The vertical cross section along $116.5^{\circ} \mathrm{E}$ in the rainstorm area (Figure 5) indicates that the key area was located between $30^{\circ} \mathrm{N}$ and $31^{\circ} \mathrm{N}$ (denoted by the red triangle in Figure 5). High equivalent potential temperature controlled this region from surface up to $900 \mathrm{hPa}$, and the equivalent potential temperature near the surface exceeded $354 \mathrm{~K}$, while a belt of dense, nearly vertically oriented contours of $\theta_{\mathrm{e}}$ appeared from $900 \mathrm{hPa}$ to $600 \mathrm{hPa}$ with large vertical gradient of $\theta_{\mathrm{e}}$ on both sides of the belt. $\theta_{\mathrm{e}}$ decreased with increasing height from surface to $800 \mathrm{hPa}$ along $30^{\circ} \mathrm{N}$ to the south of the dense $\theta_{\mathrm{e}}$ belt, indicating an instable atmospheric stratification. Along $33^{\circ} \mathrm{N}$ to the north of the dense $\theta_{e}$ belt, $\theta_{e}$ decreased with increasing height from surface to $700 \mathrm{hPa}$, suggesting that the atmospheric instability was even stronger than that to the south. From ground to the upper troposphere in the key area of the rainstorm, the atmospheric column is moist with the relative humidity exceeding $60 \%$ throughout the column, and the relative humidity is higher than $90 \%$ from surface to $400 \mathrm{hPa}$. The relative humidity is higher than $60 \%$ to the north of the key area and below $800 \mathrm{hPa}$ to the south. A vertical belt of isothermal advection formed at the interface of the cold and warm air mass over the key area of the rainstorm, with strong cold advection above the region between $29^{\circ} \mathrm{N}$ and $31^{\circ} \mathrm{N}$ and warm advection to the northern and southern sides of this region. The above analysis shows that at the beginning of the rainstorm, there existed sufficient water vapor above the key area of the rainstorm while the atmospheric stratification is unstable on both sides of it. Such a pattern of synoptic weather system provided unstable energy, sufficient water vapor, 


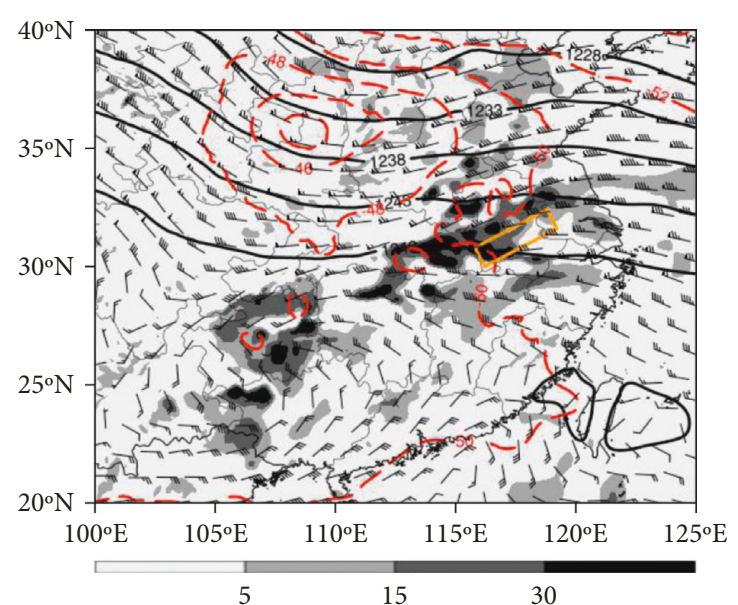

(a)

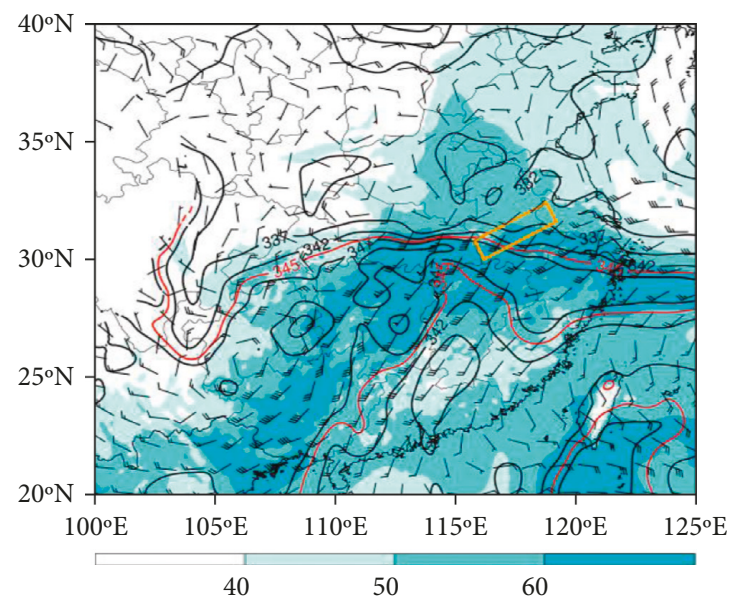

(c)

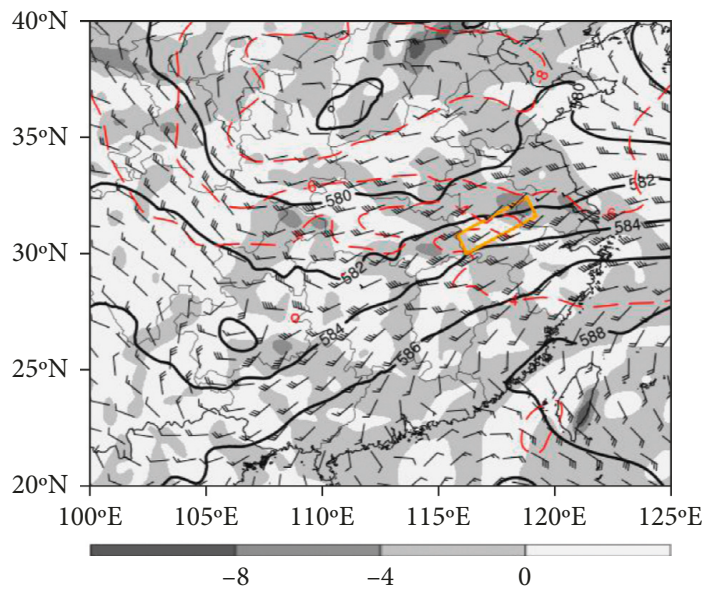

(b)

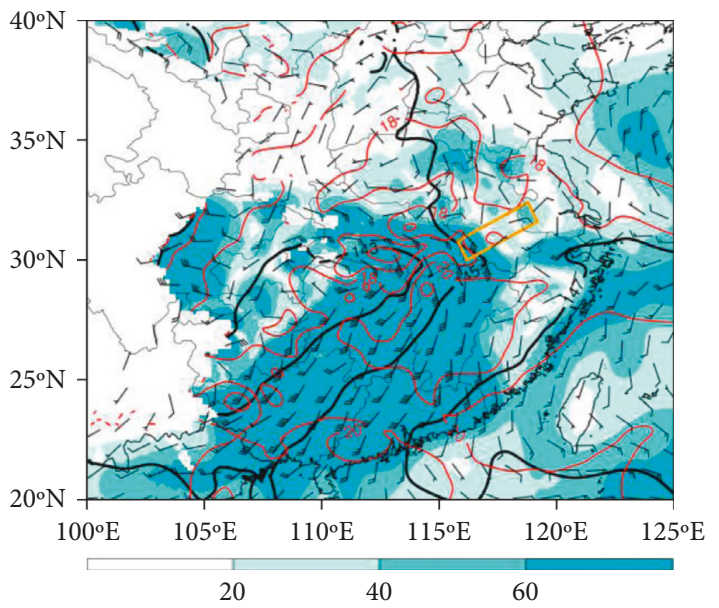

(d)

FIgURE 4: Large-scale background at 0000 UTC 4 July 2014: (a) winds (wind barbs, each long barb represents $4 \mathrm{~m} \cdot \mathrm{s}^{-1}$, the same hereafter), geopotential height (black solid contours, unit: $10 \mathrm{dgpm}$ ), temperature (red dashed lines, unit: ${ }^{\circ} \mathrm{C}$ ), and horizontal divergence (shaded in grey, unit: $10^{-5} \cdot \mathrm{s}^{-1}$ ) at $200 \mathrm{hPa}$, and the yellow frame denotes the key area of the rainstorm; (b) same as (a) but for $500 \mathrm{hPa}$, and the areas shaded in grey show temperature advection (unit: $10^{-5} \cdot \mathrm{K} \cdot \mathrm{s}^{-1}$ ); (c) equivalent potential temperature black solid lines, unit: $\mathrm{K}$; the red lines indicate the isolines of $345 \mathrm{~K}$ and vertically integrated precipitable water (unit: $\mathrm{mm}$ ) at $700 \mathrm{hPa}$; (d) same as (a) but for $850 \mathrm{hPa}$, and the shaded areas indicate water vapor flux (unit: $\mathrm{m} \cdot \mathrm{g} \cdot \mathrm{s}^{-1} \cdot \mathrm{kg}^{-1}$ ).

and dynamic lifting for subsequent formation of the rainstorm.

3.2. Evolution Characteristics of the Rainstorm System. Radar echoes at $3 \mathrm{~km}$ (Figure 6) are implemented to analyze the evolution of the rainstorm system. From the daytime on 3 July to the morning of 4 July 2014, heavy precipitation largely occurred in southeastern Hubei. In central southern Anhui, heavy precipitation mainly occurred from the daytime of 4 July to the nighttime of 5 July 2014. Radar echoes show consecutive genesis of mesoscale convective system that propagated towards the key area from southwest to northeast. At 0300 UTC 4 July (Figure 6(a)), strong echo center was located at southeastern Hubei, while small-scale radar echo center was also found in the key area and maintained there in the subsequent three hours. At 0600 UTC (Figure 6(b)), radar echoes in southeastern Hubei weakened, and the strong echo center with the size of around $20-50 \mathrm{~km}$ was located at the key area of the rainstorm. Large areas of weak echoes were found to the north of the key area, suggesting that during 00-06 UTC 4 July, the rainstorm mainly comprised deep convective precipitation in the south and stratocumulus precipitation in the north. The strong echoes kept propagating northeastward in the subsequent three hours, and the mesoscale convective system moved to east of the key area of the rainstorm by 0900 UTC 4 July (Figure 6(c)). Meanwhile, new convective system formed in southwestern Hubei and intensified during its moving to the northeast. By 1200 UTC 4 July, the newly generated convective system moved to the west of the key rainstorm area (Figure 6(d)). At the same time, new convective system also formed to the southeast of the key rainstorm area. At 1500 UTC (Figure 6(e)), the convective system to the southeast developed vigorously, while weak echoes continuously formed to the west of the key area. At 1800 UTC (Figure 6(f)), 


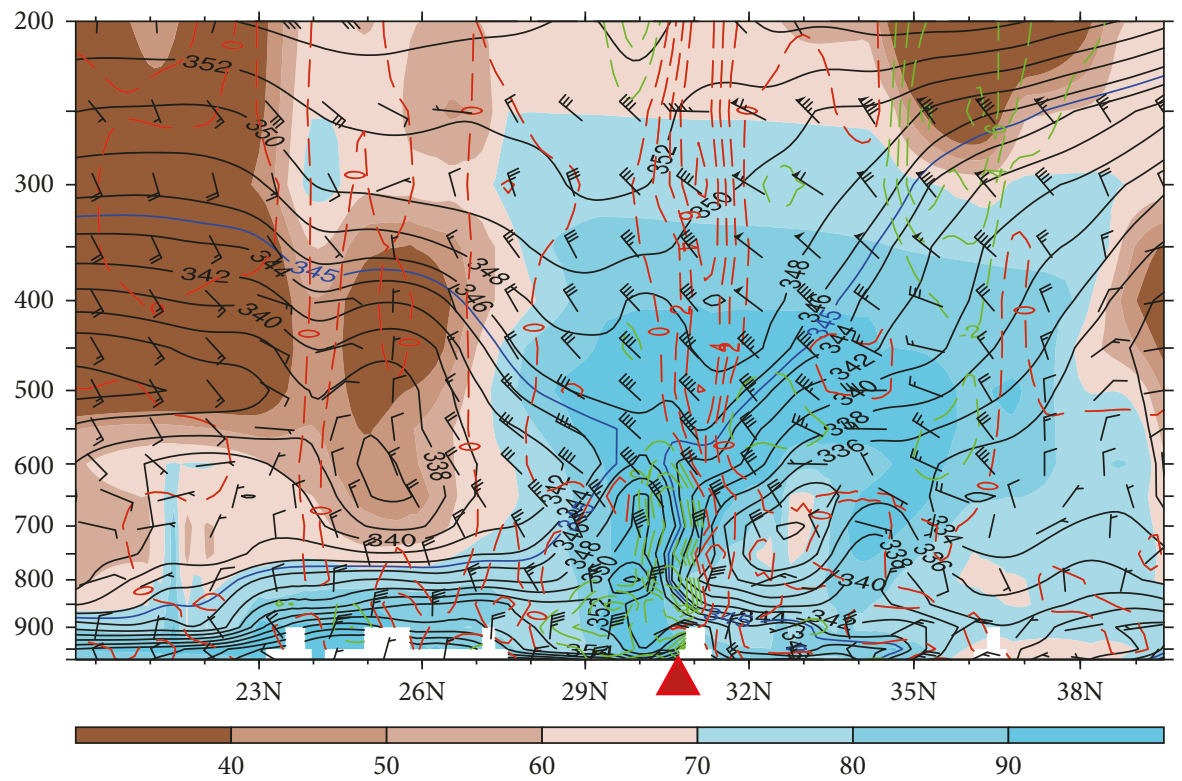

Figure 5: Vertical cross section along $116.5^{\circ} \mathrm{E}$ of equivalent potential temperature black solid lines, unit: $\mathrm{K}$ the blue line is the isoline of $345 \cdot \mathrm{K}$, horizontal winds (wind barbs), temperature advection (red dashed lines: $\geq 0^{\circ} \mathrm{C}$, green dashed lines: $<0^{\circ} \mathrm{C}$ ), relative humidity $($ shaded, unit: \%). The red triangle denotes the key area of the rainstorm and the vertical coordinate is pressure (unit: $\mathrm{hPa}$ ).

the newly developed echoes to the west of the key area intensified and moved eastward. At 2100 UTC (Figure 6(g)), a few convective cells on the scale of around $20-50 \mathrm{~km}$ were found in the key area, and the echo intensity was greater than $45 \mathrm{dBZ}$. Since then, the convective system decayed and eventually disappeared. By 0000 UTC 5 July, only weak echoes were found in the key area of the rainstorm.

The convective system in the key area of the rainstorm apparently experienced three stages. In the first stage, convective cells were largely distributed to the west of the key area and maintained there for about 5-6 hours from 0000 UTC to 0600 UTC 4 July; in the second stage, new weak echoes kept developing and intensified during their eastward moving until they moved out of the key area. This stage lasted for about 10 hours from 0700 to 1700 UTC 4 July; in the third stage, strong convective cells continuously formed in central and southeastern portion of the key area. These strong convective cells maintained for about five hours from 1700 UTC to 2200 UTC 4 July. The convective cells that formed the mesoscale convective belt propagated from southwest to northeast across the key rainstorm area, resulting in large accumulative precipitation in this area. This is the main reason for the rainstorm occurrence in this region. This phenomenon is often called echo training [20]. The third stage is the mature stage of the rainstorm, and the maximum precipitation occurred at about 1800 UTC.

Time-distance distribution of hourly precipitation in the key rainstorm area is shown in Figure 7, which indicates that during the entire rainstorm process, there existed three heavy rain belts that moved from southwest to northeast along the heavy rainfall axis EF (shown in Figure 2). The three heavy rain belts corresponded to the meso- $\beta$ precipitation system with the horizontal scale of $20-250 \mathrm{~km}$ that moved from southwest to northeast. Its time scale is $1-8$ hours. The first rainstorm system occurred in the first five hours, and the rainstorm center was located within $1.5^{\circ}$ to the west of key rainstorm area with averaged hourly precipitation larger than $16 \mathrm{~mm}$. The maximum precipitation occurred at the 4 th hour, and the precipitation intensity was stronger than $20 \mathrm{~mm} \cdot \mathrm{h}^{-1}$. The second rainstorm system occurred during 4-16 hours, when the precipitation was relatively weak but lasted longer. This system covered the entire key rainstorm area during its moving. The third rainstorm system occurred during 14-23 hours, when the precipitation intensity was the strongest and the system moved over a large area and lasted longer than the previous two systems. Precipitation during this period demonstrated the so-called "rainbelt training" phenomenon. The distribution and evolution of hourly precipitation were quite similar to that of radar echo observations (Figure 6), suggesting that the corrected radar reflectivity assimilated by LAPS can provide optimal initial condition for numerical models. The simulated "rainbelt training" is similar to the observed "echo training."

\section{Mechanism for the Initiation and Development of the Rainstorm System}

4.1. Atmospheric Stability. Domain-averaged convective available potential energy (CAPE) and convective inhibition $(\mathrm{CIN})$ in the rainstorm area are computed at each level (Figure 8) to analyze the distribution of atmospheric energy. Figure 8 shows that in the first six hours, CAPE was small and decreased with time, while the maximum CAPE occurred at about $500 \mathrm{~m}$ in lower level. CAPE decreased from $370 \mathrm{~J} \cdot \mathrm{kg}^{-1}$ at $0300 \mathrm{UTC}$ to $300 \mathrm{~J} \cdot \mathrm{kg}^{-1}$ at $0600 \mathrm{UTC} 4 \mathrm{July}$, corresponding to weak precipitation in the first stage (0-6 hours) shown in Figure 3. Since then, the maximum CAPE 


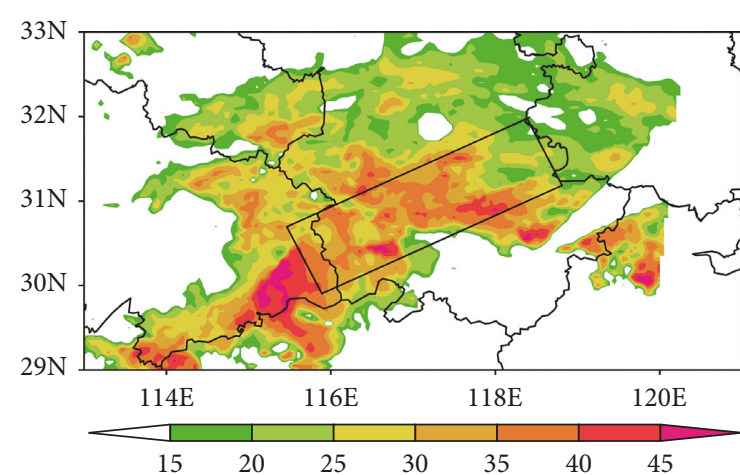

(a)

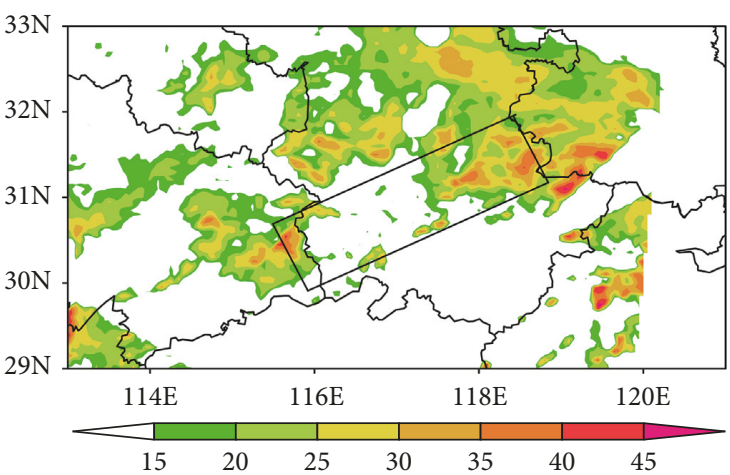

(c)

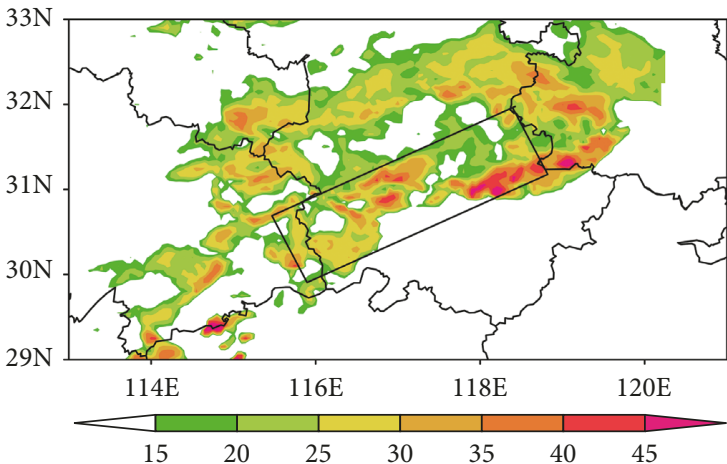

(e)

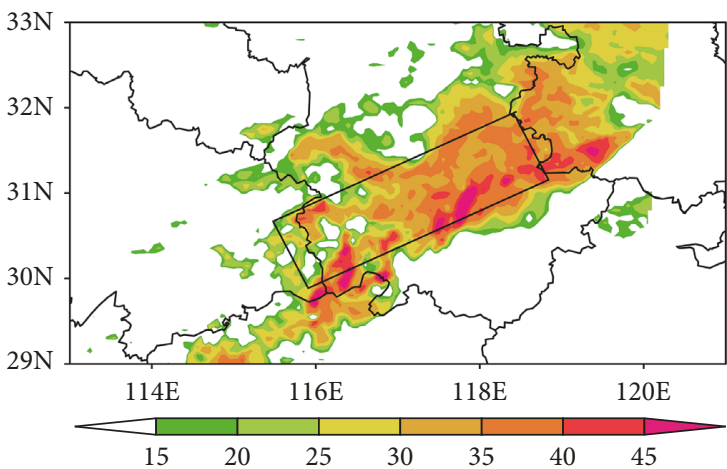

(g)

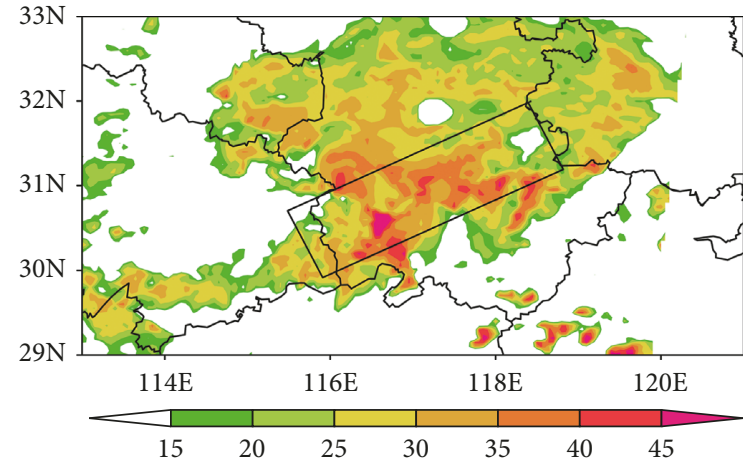

(b)

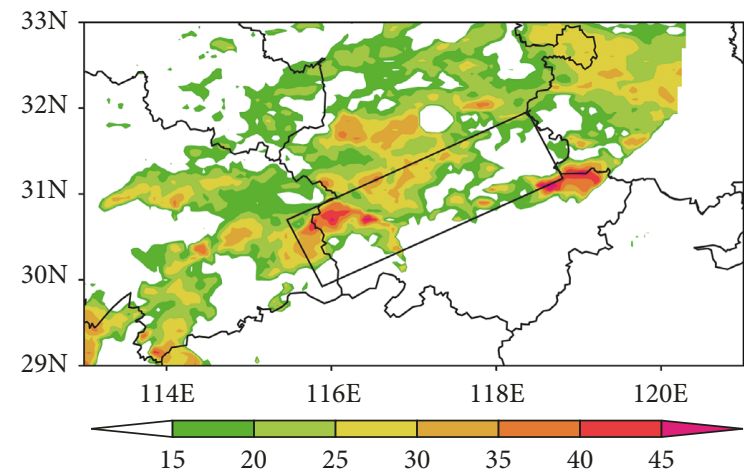

(d)

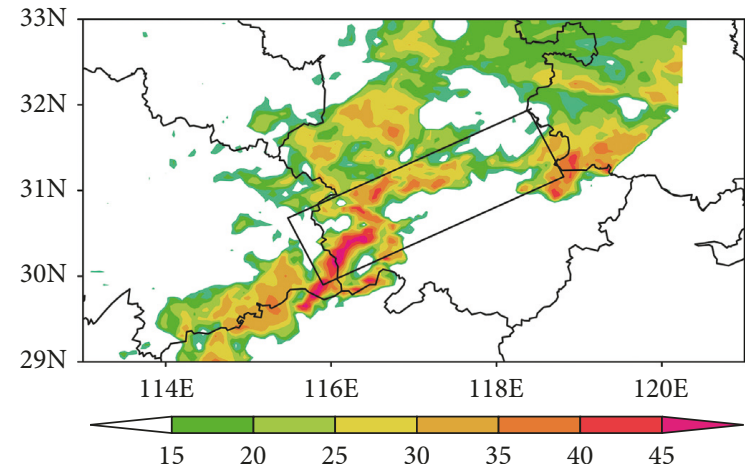

(f)

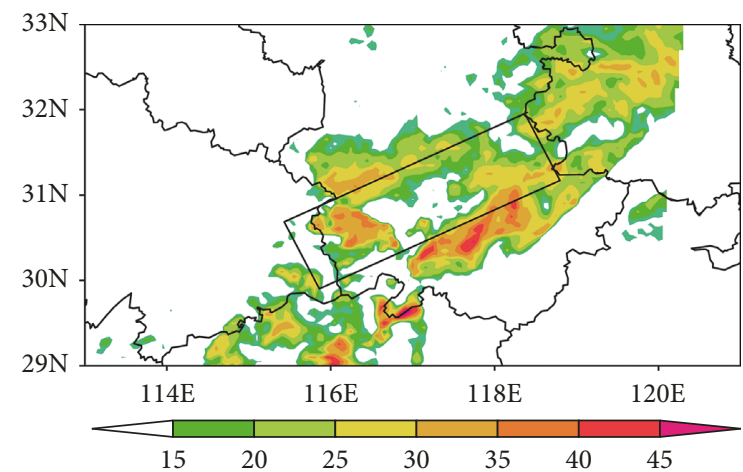

(h)

FIgURE 6: Observed radar echoes at the height of $3 \mathrm{~km}$ during 0300 UTC 4 July-0000 UTC 5 July at 3-h intervals (a) 0300 UTC 4 July; (b) 0600 UTC 4 July, (c) 0900 UTC 4 July; (d) 1200 UTC 4 July; (e) 1500 UTC 4 July; (f) 1800 UTC 4 July; (g) 2100 UTC 4 July; (h) 0000 UTC 5 July. Unit: dBZ. The black frame indicates the key rainstorm area. 


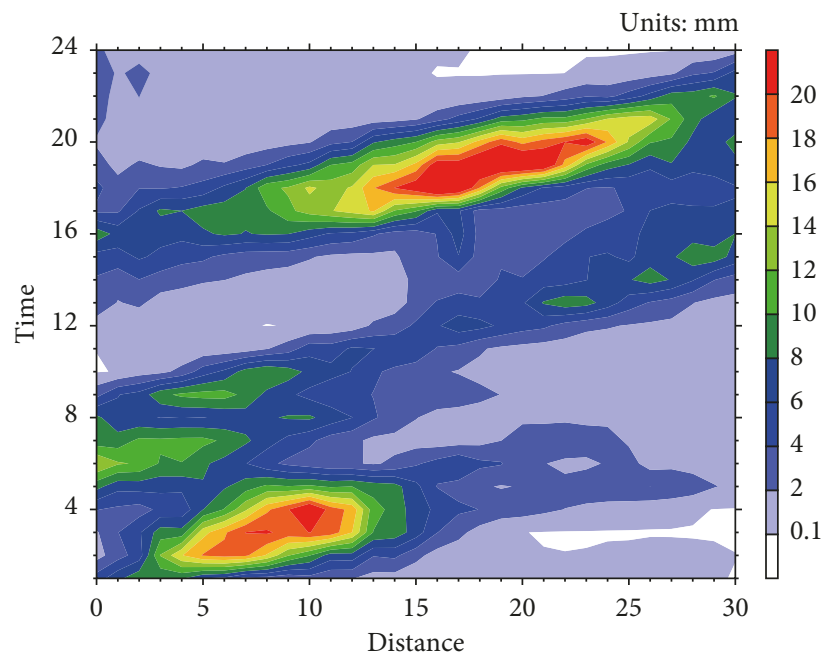

Figure 7: Temporal evolution of hourly precipitation (unit: $\mathrm{mm} \cdot \mathrm{h}^{-1}$ ) averaged over all grids along AB (shown in Figure 2(a)) in the key rainstorm area (the white frame shown in Figure 2(a)). $X$-axis indicates the distance (unit: $10 \mathrm{~km}$ ) to the western boundary (i.e., $A B$ ) of the key rainstorm area along the BD direction (shown in Figure 2(a)). $Y$-axis shows the forecasting time (unit: hour) from 0000 UTC 4 -0000 UTC 5 July.

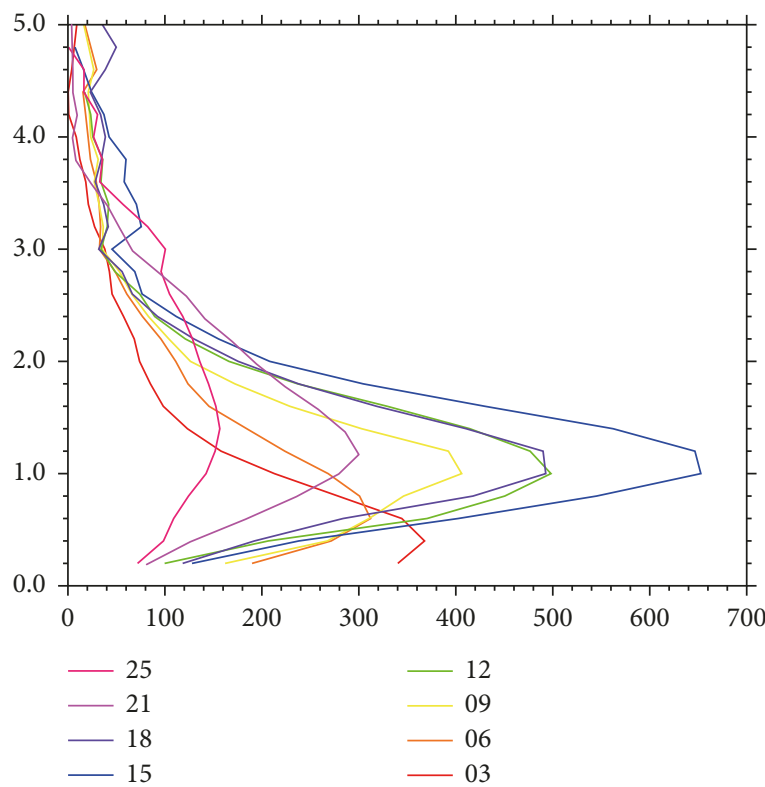

(a)

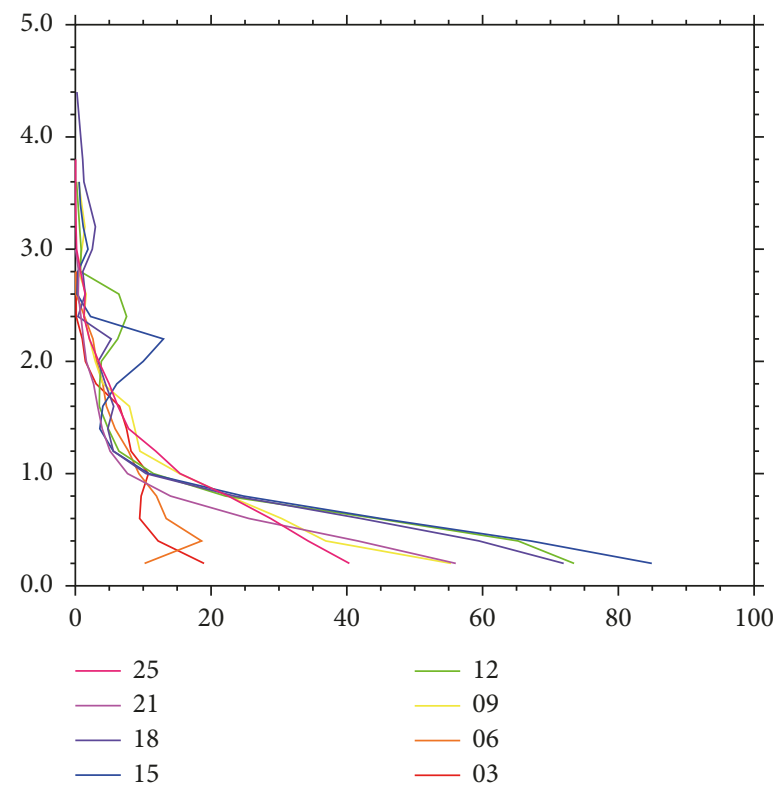

(b)

FIGURE 8: Vertical profiles of domain-averaged CAPE (a) and CIN (b) (unit: $\mathrm{J} \cdot \mathrm{kg}^{-1}$ ) in the rainstorm area at various times $03-24 \mathrm{~h}$ from 0300 UTC 4 -0000 UTC 5 July per 3 hours. $Y$-axis indicates the vertical height (unit: km).

remained at about the height of $1 \mathrm{~km}$ and its value increased from $300 \mathrm{~J} \cdot \mathrm{kg}^{-1}$ to $650 \mathrm{~J} \cdot \mathrm{kg}^{-1}$ at $1500 \mathrm{UTC} 4 \mathrm{July}$, and then decreased to $150 \mathrm{~J} \cdot \mathrm{kg}^{-1}$ at 0000UTC 5 July. CAPE in the lower levels was small during the entire process. Comparison of CAPE during the heavy rainfall period of 1300 UTC-2300 UTC and that at the maximum rainfall time of 1900 UTC 4 July; it is found that CAPE gradually increased before the heavy rainfall occurred. CAPE was released when the heaviest rainfall occurred and then gradually decreased. The distribution of CIN was consistent with that of CAPE. CIN remained large in lower levels and small above the height of $1 \mathrm{~km}$, suggesting that CAPE was small in lower levels and the atmosphere was stable. Overall, the atmosphere was stable in lower levels with low CAPE but unstable in the upper level with continuously increasing CAPE during the rainstorm process. 


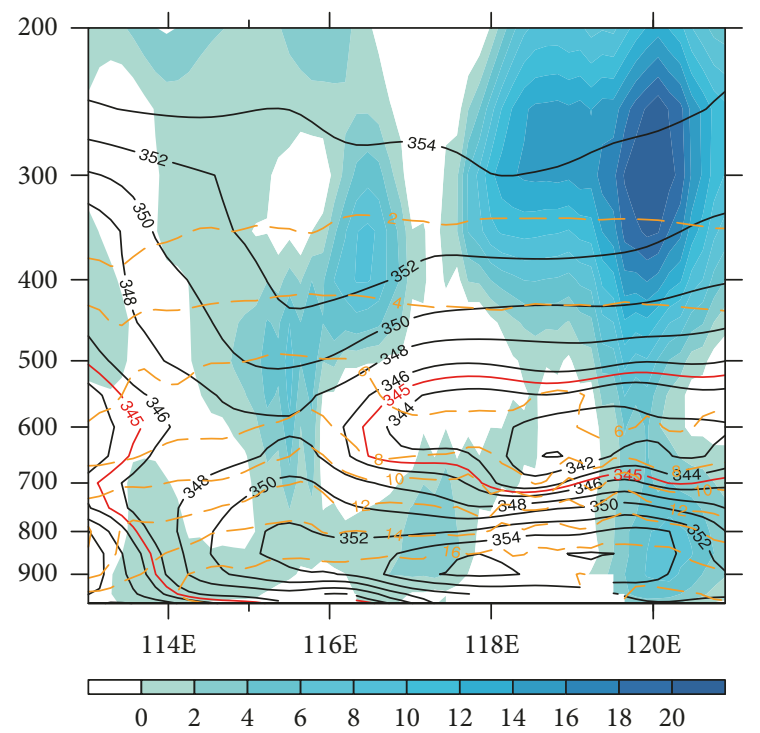

(a)

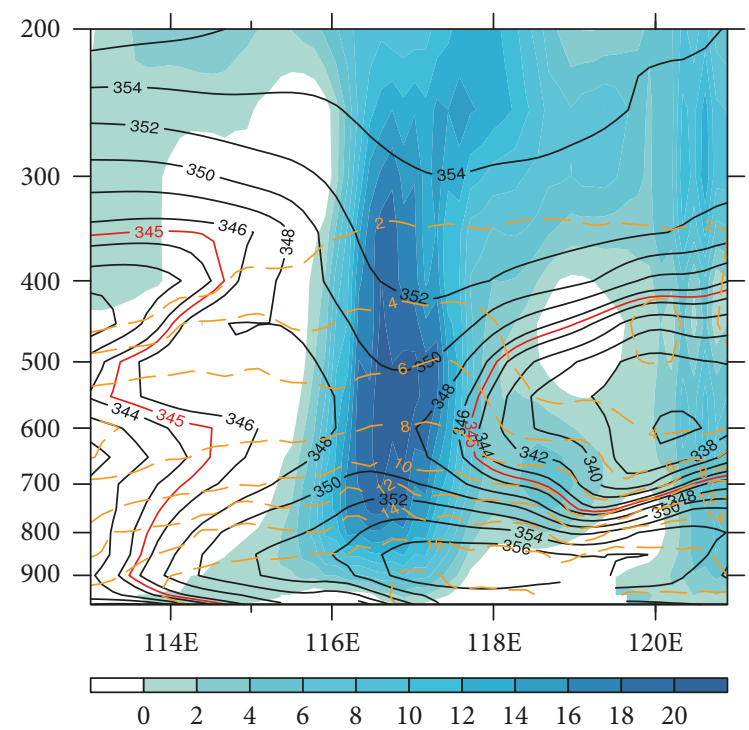

(b)

Figure 9: Vertical cross sections along $31^{\circ} \mathrm{N}$ of equivalent potential temperature black solid lines, unit: K; the red solid lines are isolines of $345 \mathrm{~K}$, specific humidity (orange dashed lines, unit: $\mathrm{g} \cdot \mathrm{kg}^{-1}$ ), vertical velocity (shaded, unit: $\mathrm{cm} \cdot \mathrm{s}^{-1}$ ) at (a) $1200 \mathrm{UTC} 4 \mathrm{July}$, (b) $1700 \mathrm{UTC} 4$ July. $\mathrm{Y}$-axis is pressure (unit: $\mathrm{hPa}$ ).

Vertical cross sections of equivalent potential temperature, specific humidity, and vertical velocity along the rainstorm center $\left(\sim 31^{\circ} \mathrm{N}\right)$ at various times are displayed in Figure 9, which shows a center of high equivalent potential temperature at $850 \mathrm{hPa}$ over the rainstorm area of $116^{\circ} \mathrm{E}-$ $118^{\circ} \mathrm{E}$ since 1000 UTC 4 July. The equivalent potential temperature decreased from lower levels upward to $850 \mathrm{hPa}$, corresponding to atmospheric instability below $850 \mathrm{hPa}$ in this region. This pattern that is favorable for the maintenance of convective instability in lower levels maintained stably in the rainstorm area except that the center of high equivalent potential temperature slowly moved eastward and was out of the rainstorm area by 2200 UTC. The heaviest precipitation occurred at 1900 UTC (Figure 3(a)). In the prior 12 hours of 1900 UTC, contours of equivalent potential temperature were densely distributed below $900 \mathrm{hPa}$ with large gradient above the western edge of the key rainstorm area along $116^{\circ} \mathrm{E}$, and ascending motion occurred from $900 \mathrm{hPa}$ up to $350 \mathrm{hPa}$ (Figure 9(a)). Convective rainfall started over the key rainstorm area. Five hours later, the strongest updraft moved to $117^{\circ} \mathrm{E}$ and vertical velocity increased (Figure 9(b)). The specific humidity exceeded $16 \mathrm{~g} \cdot \mathrm{kg}^{-1}$ below $850 \mathrm{hPa}$ during the entire rainfall process, suggesting favorable water vapor condition for rainfall.

The above analysis shows that over the rainstorm area, convective instability in lower levels, strong ascending motion during the heavy rainfall period, and abundant water vapor coexisted, leading to favorable condition for heavy rainfall. Convective instability is a kind of potential instability that needs external uplift forcing as a triggering mechanism. It is necessary to study how the low-level unstable energy was triggered and released that subsequently resulted in heavy rainfall during the rainstorm process.
4.2. Low-Level Jet. LLJ is regarded as the most important mechanism that supplies moisture and energy for midlatitude rainstorms. LLJ can rapidly transport warm, moist air mass and lead to strong moisture convergence. Momentum, water vapor, and heat fluxes often accumulate in the planetary boundary layer due to the effect of LLJ before they are transported upwards.

Figure 4(c) indicates that, at the initial time, the southwesterly LLJ at $700 \mathrm{hPa}$ was located to the southwest of the key rainstorm area with the jet axis in the area $\left(29-30^{\circ} \mathrm{N}\right.$, $\left.113-115^{\circ} \mathrm{E}\right)$. This southwesterly LLJ transported water vapor to the key rainstorm area downstream. Many previous studies have shown that the southwesterly LLJ is closely linked to Meiyu frontal rainstorm. Vertical cross sections of water vapor flux and horizontal winds along $29^{\circ} \mathrm{N}$ at various times are shown in Figure 10, which is used to analyze changes in the LLJ to the southwest of the rainfall system during the rainstorm process.

The simulated heaviest rainfall in the key rainstorm area occurred at 1900 UTC 4 July (Figure 3(a)). Cross sections along $29^{\circ} \mathrm{N}$ (Figure 10) show that LLJ maintained in the upstream to the southwest of the key rainstorm area, and the LLJ slowly moved eastward. Figure 10(a) displays low-level winds and water vapor flux below $3 \mathrm{~km}$ eight hours (1100 UTC) prior to the second stage of heavy rainfall. It is found that horizontal winds between $1.6 \mathrm{~km}$ and $3 \mathrm{~km}$ that exceeded $16 \mathrm{~m} \cdot \mathrm{s}^{-1}$ were largely distributed over $113^{\circ} \mathrm{E}-$ $117^{\circ} \mathrm{E}$, where high water vapor fluxes larger than $90 \mathrm{~g} \cdot \mathrm{kg}{ }^{-1} \cdot \mathrm{m} \cdot \mathrm{s}^{-1}$ also occurred. In the subsequent several hours, the LLJ kept intensifying and moving eastward, while the area of large water vapor flux expanded simultaneously to reach $120^{\circ} \mathrm{E}$ and extended downward to the height of $600 \mathrm{~m}$ (Figure 10(b)). 


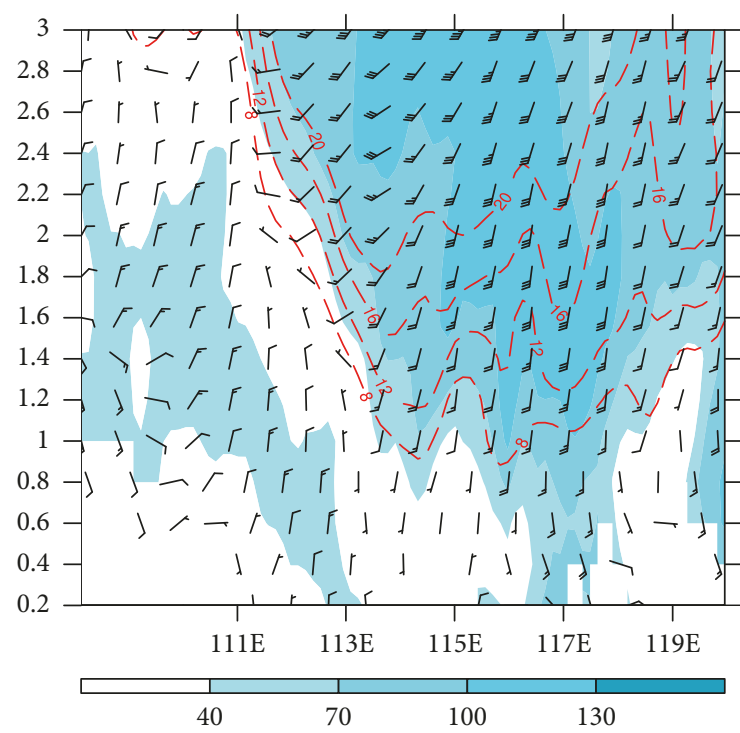

(a)

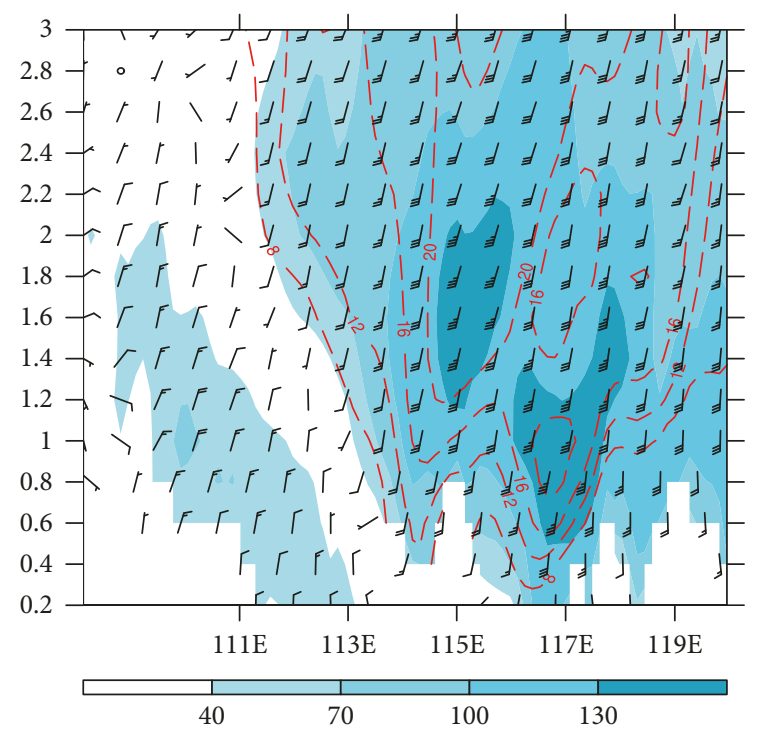

(b)

FIGURE 10: Vertical cross sections along $29^{\circ} \mathrm{N}$ of water vapor flux (shaded, unit: $\mathrm{g} \cdot \mathrm{kg}^{-1} \cdot \mathrm{m} \cdot \mathrm{s}^{-1}$ ), horizontal winds (wind barbs), and horizontal wind speed (red dashed lines, unit: $\mathrm{m} \cdot \mathrm{s}^{-1}$ ) at 9 (a) 1100 UTC 4 July and (b) 1700 UTC 4 July. $Y$-axis indicates vertical height (unit: km).

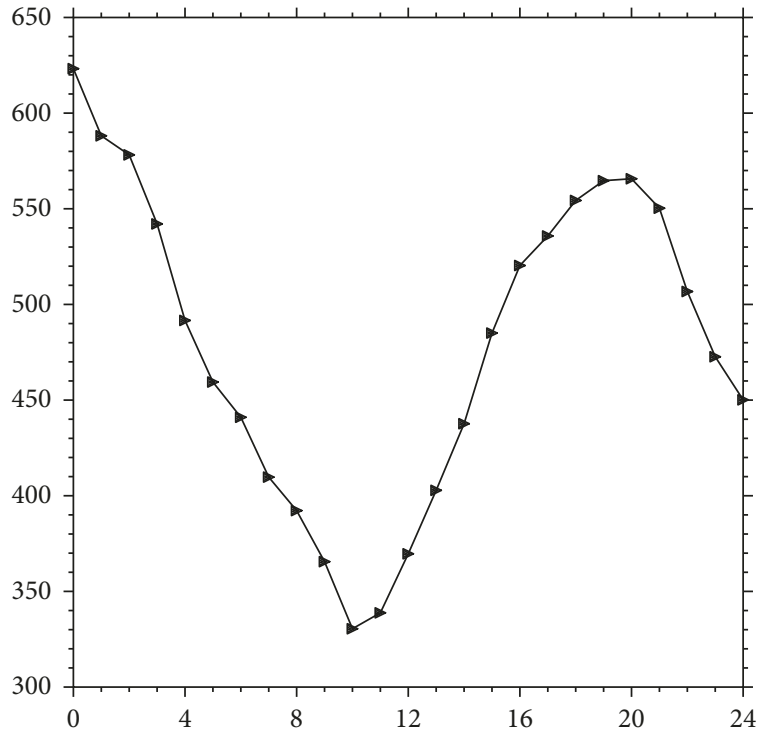

FIGURE 11: Temporal evolution of vertically integrated water vapor flux (unit: $\mathrm{g} \cdot \mathrm{kg}^{-1} \cdot \mathrm{m} \cdot \mathrm{s}^{-1}$ ) from surface to $850 \mathrm{hPa}$ averaged over $\left(113^{\circ}-118^{\circ} \mathrm{E}, 28^{\circ}-30^{\circ} \mathrm{N}\right)$. $X$-axis indicates the forecasting time 0 24 h from 0000 UTC 4-0000 UTC 5 July 2014.

Temporal evolution of vertically integrated water vapor flux from surface to $850 \mathrm{hPa}$ averaged over the LLJ domain to the south of the key rainstorm area (Figure 11) shows that the low-level water vapor decreased with time in the first 10 hours from $623 \mathrm{~g} \cdot \mathrm{kg}^{-1} \cdot \mathrm{m} \cdot \mathrm{s}^{-1}$ to $330 \mathrm{~g} \cdot \mathrm{kg}^{-1} \cdot \mathrm{m} \cdot \mathrm{s}^{-1}$. This is because the first-stage heavy precipitation was decaying during this period. Since then, the LLJ intensified and water vapor flux increased, providing sufficient water vapor condition for the development of the second-stage heavy precipitation. The water vapor transport gradually intensified during a 10-h period from 1000 UTC to 2000 UTC 4 July and the value increased to $565 \mathrm{~g} \cdot \mathrm{kg}^{-1} \cdot \mathrm{m} \cdot \mathrm{s}^{-1}$. This period corresponded to the stage for the rainstorm to develop and mature in the key rainstorm area, suggesting that the LLJ provided enough energy for the rainstorm system. The intensification of lowlevel convergence was a critical reason for precipitation to reach its maximum in the key rainstorm area.

4.3. Steering Flow in the Mid-level. The synoptic steering flow is analyzed based on changes of domain-averaged horizontal wind with height in the western half of the key rainstorm area (Figure 12) at various times during the development stage of the rainstorm system. During 1400-1800 UTC 4 July when the rainstorm was developing, easterly winds with the speed less than $10 \mathrm{~m} \cdot \mathrm{s}^{-1}$ prevailed in lower levels from $975 \mathrm{hPa}$ to $925 \mathrm{hPa}$, while the meridional winds were relatively weak with wind speed within 1 to $7 \mathrm{~m} \cdot \mathrm{s}^{-1}$. From $850 \mathrm{hPa}$ to $200 \mathrm{hPa}$, westerly winds prevailed and the wind speed increased with height from $2 \mathrm{~m} \cdot \mathrm{s}^{-1}$ to $20 \mathrm{~m} \cdot \mathrm{s}^{-1}$, and the meridional wind speed is about $10 \mathrm{~m} \cdot \mathrm{s}^{-1}$. The wind speed at $700 \mathrm{hPa}$ remained almost unchanged in five hours, and the westerly wind speed was around $10 \mathrm{~m} \cdot \mathrm{s}^{-1}$. The above results indicate that above the convective region, the rainstorm system moved northeastward following the southwesterly winds, which were the major steering flow in the midlevel.

\section{Structure Characteristics of the Rainstorm System at Its Mature Stage and the Mechanism for Its Decaying}

5.1. Horizontal Distribution of Vertical Motion at the Mature Stage. Vertical motion is highly correlated with the triggering and release of unstable energy in rainstorm systems and precipitation. Analysis of the vertical velocity $(w)$ and its 


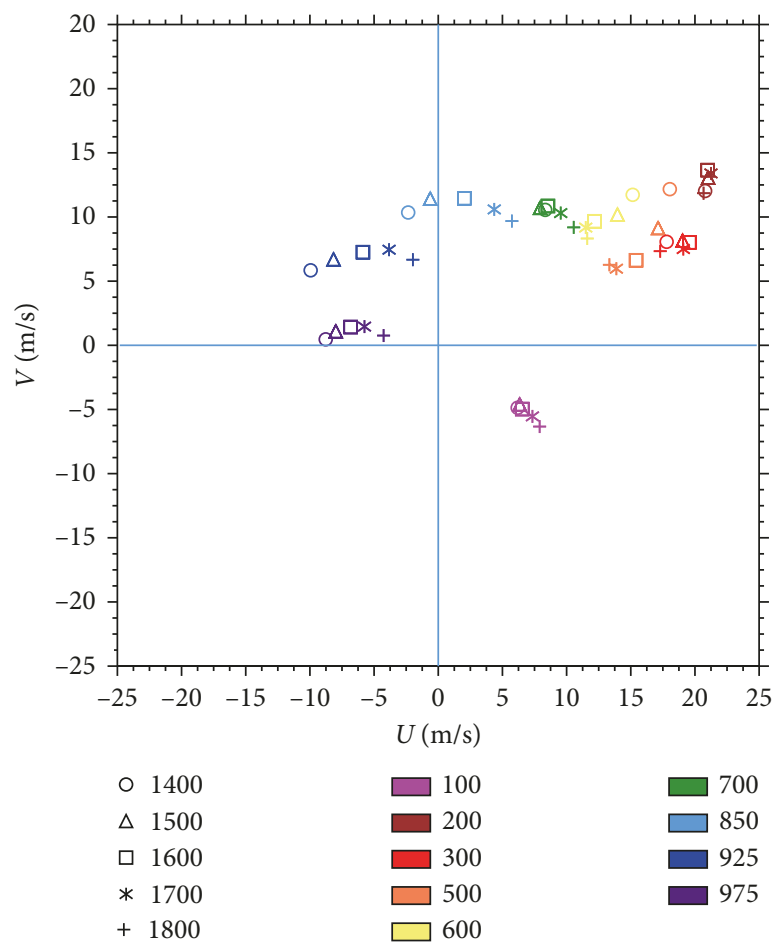

FIGURE 12: Changes of domain averaged horizontal wind with height in the western half of the key rainstorm area during 1400-1800 UTC 4 July 2014. Different colors represent different heights (unit: hPa).

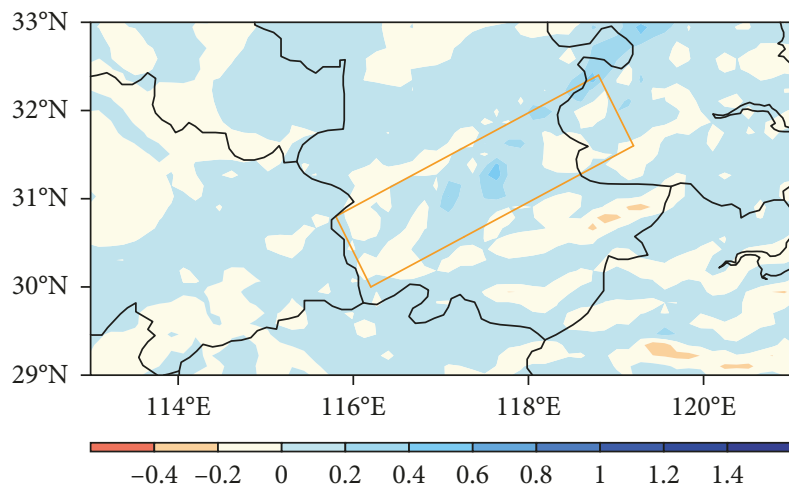

(a)

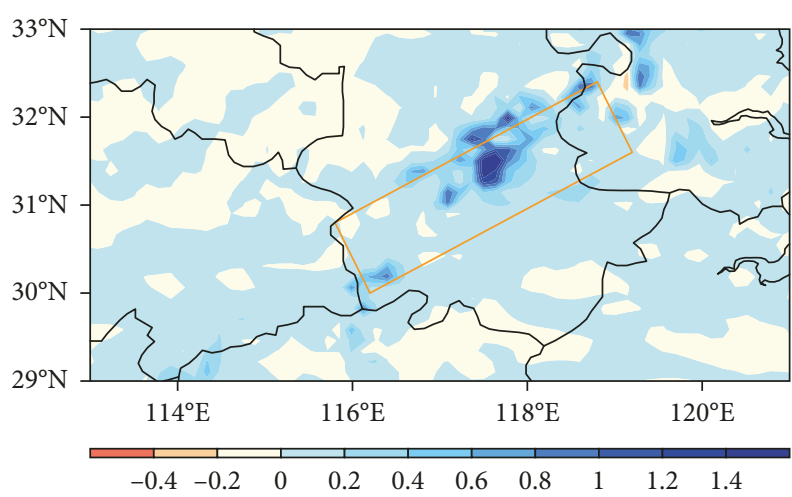

(c)

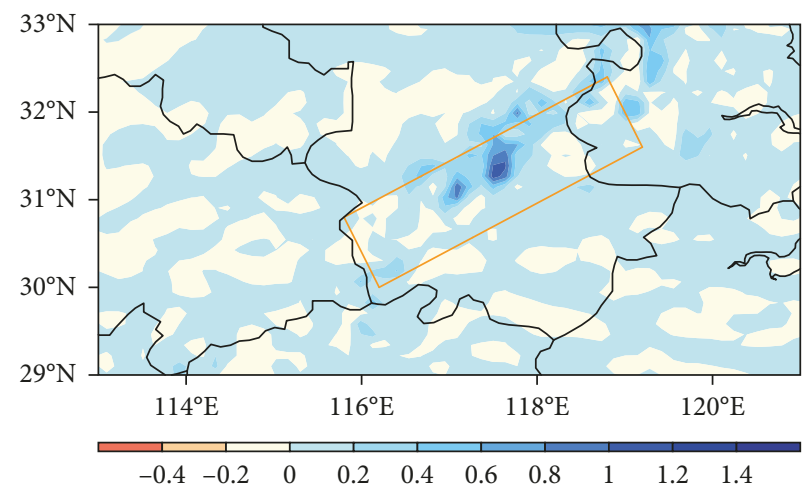

(b)

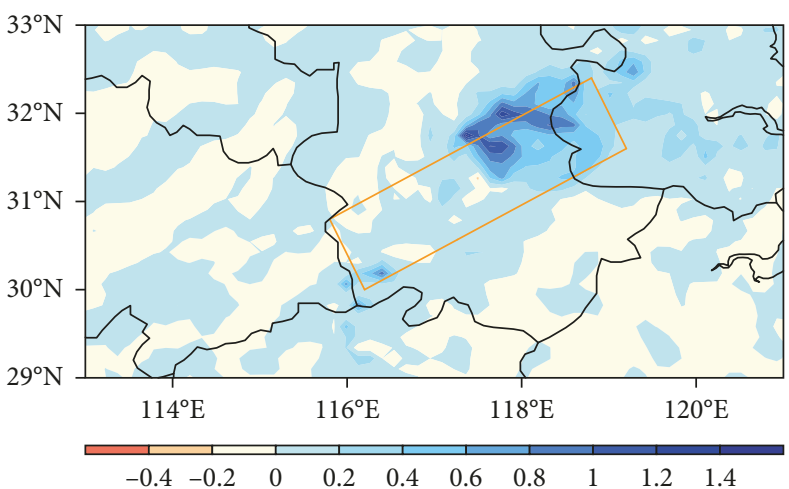

(d)

FIGURE 13: Vertical velocities averaged over 1800-2000 UTC 4 July 2014 (shaded, unit: $\mathrm{m} \cdot \mathrm{s}^{-1}$ ) at various heights (a) $1 \mathrm{~km}$, (b) $3 \mathrm{~km},(\mathrm{c}) 5 \mathrm{~km}$, and (d) $10 \mathrm{~km}$. 
characteristic changes will be helpful to reveal the physical and dynamical processes in the rainstorm system. Horizontal distributions of vertical velocity $w$ at various heights are presented in Figure 13, which shows that strong ascending motion was located in the key area during the mature stage of the rainstorm and extended to upper levels. Ascending motions in other areas were weak. At the height of $1 \mathrm{~km}$ (Figure 13(a)), vertical motion was weak over the entire system with the maximum temporal average being about $0.4 \mathrm{~m} \cdot \mathrm{s}^{-1}$, and the ascending motion was largely found in central key area of the rainstorm. At the height of $3 \mathrm{~km}$ (Figure 13(b)), the ascending motion was relatively strong with the maximum temporal average of $1 \mathrm{~m} \cdot \mathrm{s}^{-1}$. At the height of $5 \mathrm{~km}$ (Figure 13(c)), the ascending motion significantly intensified compared with that in the lower troposphere. The temporal average of vertical velocity exceeded $2 \mathrm{~m} \cdot \mathrm{s}^{-1}$ and strong vertical motions were largely distributed in the central key area. In the upper level of $10 \mathrm{~km}$ (Figure 13(d)), the ascending motion was slightly weaker than that in the middle level, and the maximum value was about $1.2 \mathrm{~m} \cdot \mathrm{s}^{-1}$ located to the northeast of the key area. Apparently, during the mature stage of the rainstorm system, ascending motion consistently occurred from low level to upper level above the key area with the largest vertical motion in the middle level. The area of ascending motion tilted northeastward with height, indicating a vertically tilted structure of the rainstorm system during its mature stage. The strong ascending motion above the key area was favorable for the formation of heavy precipitation.

5.2. Changes in Ambient Atmospheric Stability. Vertical profiles of CAPE and CIN averaged over the key area during the decaying period of the rainstorm are displayed in Figure 14, which shows that following the decaying of the system, the maximum CAPE at the height of $1.5 \mathrm{~km}$ decreased from $350 \mathrm{~J} \cdot \mathrm{kg}^{-1}$ at $2000 \mathrm{UTC}$ to $170 \mathrm{~J} \cdot \mathrm{kg}^{-1}$ at 2300 UTC. The atmospheric stratification in lower levels became more stable, but CIN below $500 \mathrm{~m}$ remained large through the process. The stable atmospheric stratification in lower levels indicated that unstable energy decreased during the decaying stage and the rainstorm could not maintain without sufficient energy.

5.3. Evolution of the Rainstorm Structure. Vertical cross sections of radar echo, equivalent potential temperature, and winds at various time along the axis of the heaviest rainfall (EF shown in Figure 2(a)) in the key rainstorm area are shown in Figure 15 for analysis of differences in echo structure, thermal structure, and circulation between the mature and decaying stages of the rainstorm system. Figure 15 shows that mesoscale convective systems on the scale of $20-50 \mathrm{~km}$ kept forming in the key rainstorm area, intensified during their northeastward moving, and eventually weakened and moved out of the area. Figure 15(a) shows the situation at 1400 UTC, which was five hours prior to the occurrence of the heaviest precipitation. Area-averaged rainfall intensity at this time was about $4 \mathrm{~mm} \cdot \mathrm{h}^{-1}$ and mainly comprised weak precipitation. $\theta_{\mathrm{e}}$ was lower between
3 and $6 \mathrm{~km}$ above the area and decreased with height below $4 \mathrm{~km}$, demonstrating convective unstable structure. The flow field was relatively flat and a new convective cell formed to the southwest of the area. Two hours later, this convective cell moved slowly and intensified. Meanwhile, air mass with high $\theta_{\mathrm{e}}$ was transported to lower troposphere by southwesterly LLJ, leading to strong ascending motion below $5 \mathrm{~km}$. The convective cell intensified and the radar echo reached $40 \mathrm{dBZ}$ (Figure 15(b)). At $1700 \mathrm{UTC}$, this convective cell further intensified and continued to move northeastward. At the same time, high $\theta_{\mathrm{e}}$ occurred throughout the entire atmospheric column, accompanied with strong ascending motion that could reach the height of $12 \mathrm{~km}$ and large echoes that exceeded $45 \mathrm{dBZ}$. The echo top increased from $7 \mathrm{~km}$ to $11 \mathrm{~km}$. Low $\theta_{\mathrm{e}}$ centers were still found below $4 \mathrm{~km}$ along both sides of the convective cell, indicating that there still existed unstable stratification there. Following the development of LLJ and abundant water vapor transport to the key rainstorm area (Figure 15(c)), new convective cells continued to form while the previously formed convective cells intensified and enlarged. At 1800 UTC, the echo top reached $13 \mathrm{~km}$ and the ascending motion further intensified. An updraft occurred at lower levels on the southern side of the convective cell and vertically extended to the height of $13 \mathrm{~km}$ on the northern side, which effectively transported water vapor upward. Large amounts of water vapor condensed into rainwater during the ascent, preparing favorable conditions for the heaviest precipitation that occurred at 1900 UTC (Figure 15(d)). At 1900 UTC when the heaviest precipitation occurred, three convective cells simultaneously developed and sequentially moved northeastward, forming the so-called "rainbelt training." Meanwhile, continuous energy release during this process broke through unstable stratification in the middle and lower levels, and high $\theta_{\mathrm{e}}$ became dominant throughout the rainstorm system (Figure $15(\mathrm{e}))$. At this time, hourly precipitation was $10 \mathrm{~mm} \cdot \mathrm{h}^{-1}$ (shown in Figure 3(a)), area-average hourly precipitation for rainfall $>15 \mathrm{~mm} \cdot \mathrm{h}^{-1}$ was $8 \mathrm{~mm} \cdot \mathrm{h}^{-1}$ (Figure $3(\mathrm{~d})$ ), indicating that precipitation at this time was largely convective precipitation. Since then, the convective system weakened in the key rainstorm area and moved northeastward. At 2100 UTC, the convective system was broken over the entire area and stratocumulus precipitation prevailed. $\theta_{\mathrm{e}}$ was lower in the middle and lower troposphere (Figure 15(f)).

Following the occurrence of the heaviest rainfall at 1900 UTC, the LLJ rapidly decreased and the water vapor transport by LLJ became much smaller. Changes in LLJ were highly correlated with the development and maintenance of rainstorm in this region. The rapid weakening of LLJ resulted in lower energy supply to this area, and the stratification in the middle and lower levels became stable, while ascending motion became weaker. As a result, the convective system could not maintain anymore and eventually disappeared.

\section{Summary and Conclusions}

Based on numerical simulations with radar data assimilation, the present study analyzes the characteristic features for 


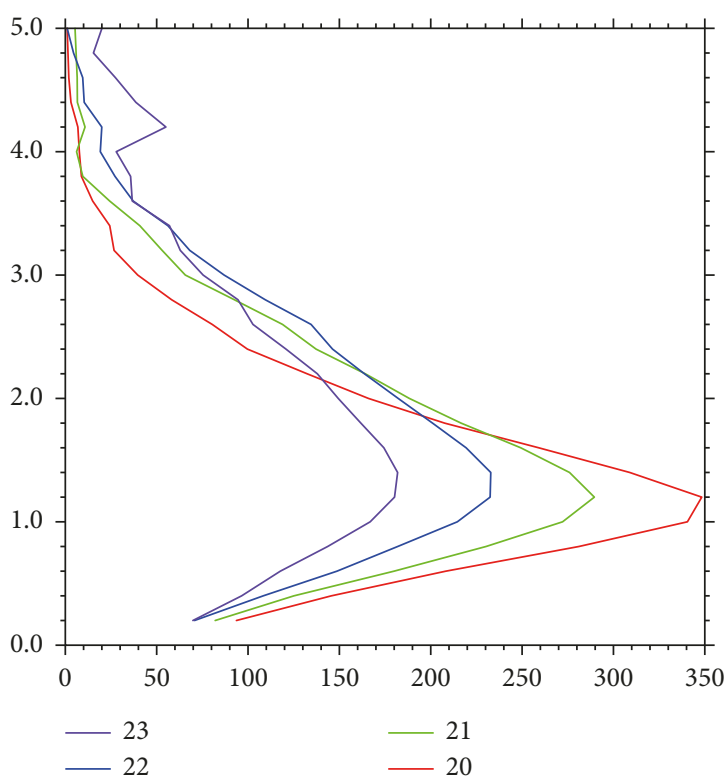

(a)

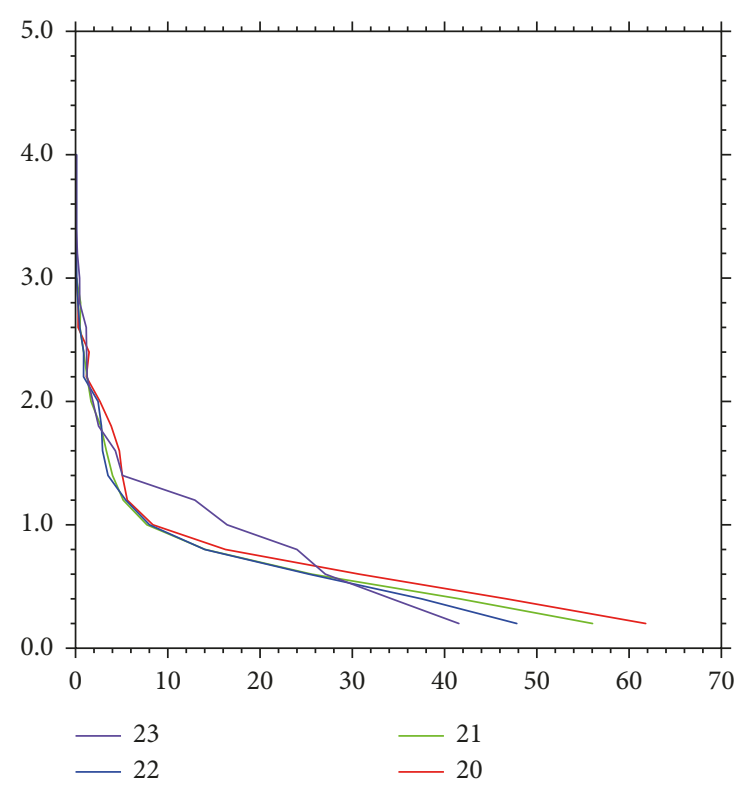

(b)

FIGURE 14: Vertical profiles of CAPE (a) and CIN (b) averaged over the key rainstorm area (units: J.kg ${ }^{-1}$ ) during $2000-2300$ UTC 4 July 2014. $Y$-axis indicates the height (unit: $\mathrm{km}$ ).

the initiation, development, and decaying of the Meiyu frontal rainstorm that occurred during 4-5 July 2014.

The results show that simulated temporal evolution of hourly precipitation agrees well with observations. Meanwhile, discrepancy is found between simulated and observed weak precipitation, and the model overestimates weak precipitation but underestimates precipitation of medium intensity. However, it can well reproduce the temporal variability of heavy precipitation and successfully simulate accumulative precipitation and precipitation evolution over the key rainstorm area. The simulated "rainbelt training" is consistent with observed "echo training" on both spatial structure and temporal evolution. Despite slight difference between the simulated and observed occurrence time of peak precipitation and difference between the maintenance periods of precipitation and echoes, the model can realistically simulate the three critical stages of precipitation.

The weather background in the lower troposphere demonstrated synoptic weather features typical for Meiyu frontal rainstorm. Significant horizontal wind shears, large humidity, and relatively weak temperature contrast could be found between northern and southern sides of the Meiyu front. The key rainstorm area was located in front of the Meiyu front, where the precipitable water was larger than $60 \mathrm{~mm}$. In addition, huge amounts of water vapor were transported to this region by strong southwesterly LLJ.

Radar echoes showed that mesoscale convective systems kept forming and propagating towards the key rainstorm area from southwest to northeast. The convective cells in the mesoscale convective belt propagated from southwest to northeast across the key rainstorm area, leading to large accumulative precipitation and rainstorm in this area.
During this rainstorm process, the vertical atmospheric structure was characterized by low energy and stable stratification in the lower levels overlapped by continuously intensifying high-energy air mass with unstable stratification. There existed convective instability in lower levels above the key rainstorm area, while strong ascending motion developed during the period of heavy rainfall. Combined with abundant water vapor supply, the above condition was favorable for the formation and development of heavy rainfall. The LLJ provided sufficient energy for the rainstorm system and intensified the low-level convergence, which was an important reason for the maintenance of precipitation system and its eventual intensification to rainstorm. The large-scale steering flow was southwesterly winds that prevailed in the middle and upper levels, which steered the rainfall system to move northeastward.

At its mature stage, the rainstorm system demonstrated vertically tilted structure with strong ascending motion in the key rainstorm area, which was favorable for the occurrence of heavy rainfall. Mesoscale convective systems on the scale of $20-50 \mathrm{~km}$ continuously formed and propagated northeastward in the key rainstorm area and eventually weakened and moved out of the area. At the time of the heaviest rainfall, three sequential convective cells formed simultaneously and moved northeastward continuously, leading to the so called "rainbelt training." Continuous energy release broke through the unstable stratification in the middle and lower levels, and heavy convective precipitation dominated the entire rainstorm process.

In the decaying stage, unstable energy decreased, and the rainstorm no longer had sufficient energy to sustain. Convective system weakened and moved northeastward, eventually became a stratocumulus precipitation system, and 


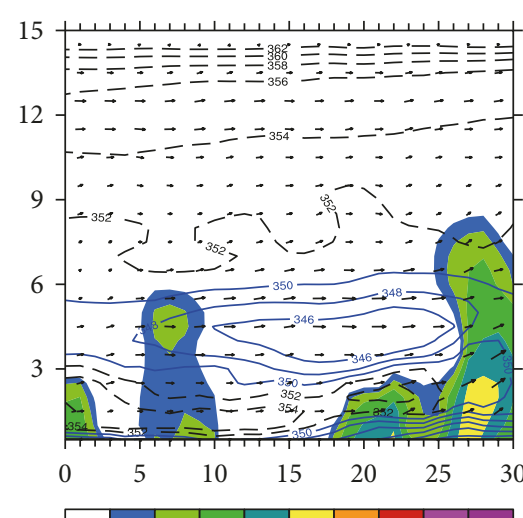

$\begin{array}{llllllllll}15 & 20 & 25 & 30 & 35 & 40 & 45 & 50 & 55\end{array}$

(a)

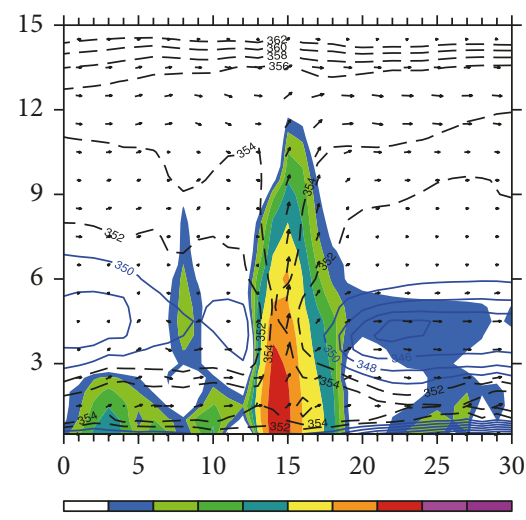

$\begin{array}{lllllllll}15 & 20 & 25 & 30 & 35 & 40 & 45 & 50 & 55\end{array}$

(c)

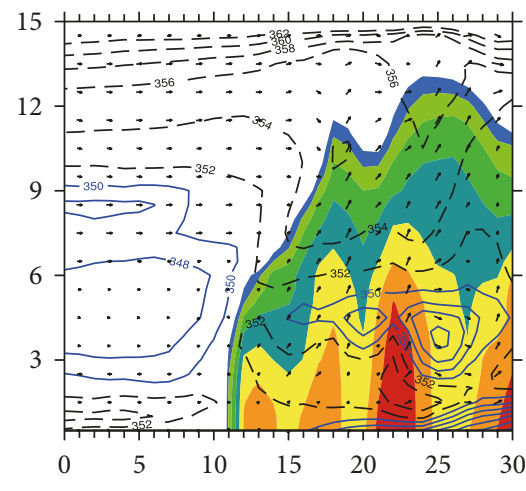

$\begin{array}{llllllllll}15 & 20 & 25 & 30 & 35 & 40 & 45 & 50 & 55\end{array}$

(e)

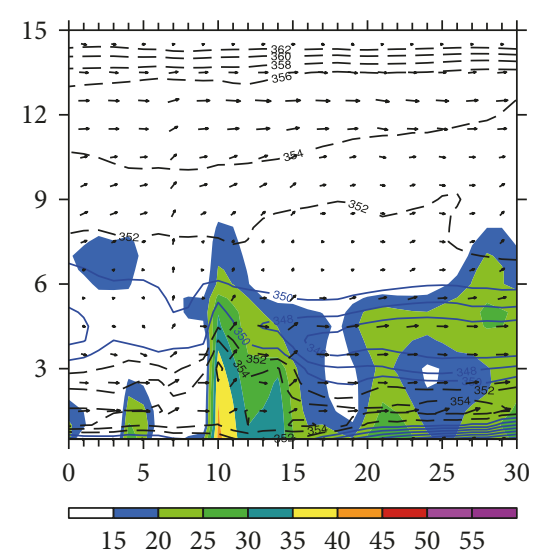

(b)

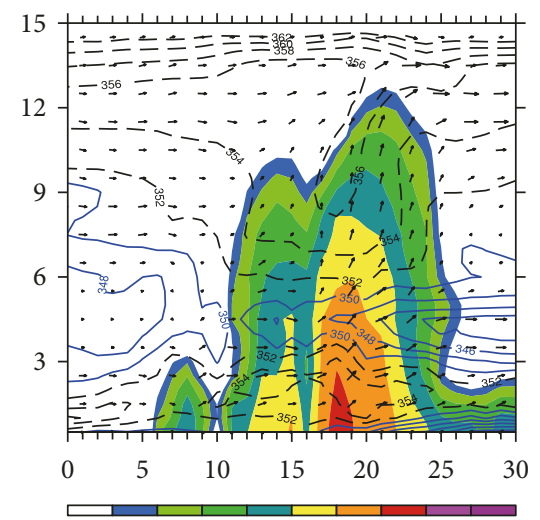

$\begin{array}{lllllllll}15 & 20 & 25 & 30 & 35 & 40 & 45 & 50 & 55\end{array}$

(d)

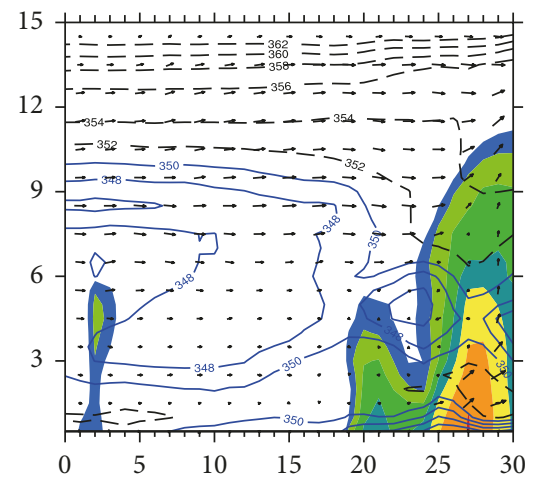

$\begin{array}{llllllllll}15 & 20 & 25 & 30 & 35 & 40 & 45 & 50 & 55\end{array}$

(f)

FIGURE 15: Vertical cross sections along EF (shown in Figure 2(a)) of radar echo (shadings, unit: dBZ), equivalent potential temperature (solid lines, unit: K blue lines for $\leq 350 \mathrm{~K}$ and black lines for $>350 \mathrm{~K}$ ), and winds at various times (a) 1400 UTC, (b) 1600 UTC, (c) 1700 UTC, (d) 1800 UTC, (e) 1900 UTC, and (f) 2100 UTC. Y-axis indicates the height (unit: km). X-axis shows the distance along the direction shown by $\mathrm{BD}$ in Figure $2(\mathrm{a})$ to the western boundary $(\mathrm{AB})$ of the key rainstorm area (unit: $\mathrm{km}$ ).

moved out of the key rainstorm area. The rapid weakening of LLJ resulted in smaller energy supply to the convective system, and the stratification tended to be stable in the middle and lower levels. The ascending motion weakened correspondingly, which made it hard for the convective system to maintain. As a result, the convective system eventually disappeared.
Our conclusions here are mainly on a Meiyu frontal rainstorm case. Perhaps, the most encouraging aspect of this entire study is that the numerical experiment can well reproduce the temporal evolution of heavy precipitation over the key rainstorm area with corrected radar reflectivity data assimilation so that we can study the characteristic features of the evolution of the Meiyu frontal rainstorm. It has 
further prompted us to vigorously pursue more Meiyu frontal rainstorm cases using real-time quantitative precipitation forecasting similar to that described here.

\section{Data Availability}

The data used to produce the results of this paper are available from the corresponding author upon request.

\section{Conflicts of Interest}

The authors declare that they have no conflicts of interest regarding the publication of this paper.

\section{Acknowledgments}

This study was supported jointly by the Key Program for International S\&T Cooperation Projects of China (Grant no. 2016YFE0109400), National Natural Science Foundation of China (Grant nos. 41620104009 and 41105072), Basic Research Foundation of IHR (Grant no. IHRKYYW201805), and Key Projects of S\&T Development Foundation of Hubei Meteorological Bureau (Grant no. 2018Z05).

\section{References}

[1] S. Y. Tao and L. Chen, "A review of recent research on the East Asia summer monsoon over China," in Monsoon Meteorology, P.-C. Chang and T. N. Krishnamuri, Eds., pp. 50-92, Oxford University Press, Oxford, UK, 1987.

[2] K. Ninomiya and T. Murakami, "The early summer rainy season (Baiu) over Japan," in Monsoon Meteorology, P.-C. Chang and T. N. Krishnamuri, Eds., pp. 93-121, Oxford University Press, Oxford, UK, 1987.

[3] Y. H. Ding, Monsoon over China, Kluwer Academic Publishers, Dordrecht, Netherlands, 1994.

[4] H. Xu, W. P. Zhang, X. X. Lang et al., "The use of dualDoppler radar data in the study of 1998 Meiyu frontal precipitation in Huaihe river basin," Advance in Atmospheric Sciences, vol. 17, no. 3, pp. 403-412, 2000.

[5] T. Akiyama, "The large-scale aspects of the characteristic features of the Baiu front," Papers in Meteorology and Geophysics, vol. 24, no. 2, pp. 157-188, 1973.

[6] Y. M. Kodama, "Large-scale common features of subtropical precipitation zones (the Baiu frontal zone, the SPCZ, and the SACZ). Part I: characteristics of subtropical frontal zones," Journal of the Meteorological Society of Japan, vol. 70, no. 4, pp. 813-836, 1992.

[7] K. Ninomiya, "Characteristics of Baiu front as a predominant subtropical front in the summer Northern Hemisphere," Journal of the Meteorological Society of Japan, vol. 62, no. 6, pp. 880-894, 1984.

[8] N. M. Truong, V. T. Hang, R. A. Pielke, C. L. Castro, and K. Dairaku, "Synoptic-scale physical mechanisms associated with the Mei-yu front: a numerical case study in 1999," AsiaPacific Journal of Atmospheric Sciences, vol. 48, no. 4, pp. 433-448, 2012.

[9] J. Zhu, D. Q. Huang, and T. Yang, "Changes of Meiyu system in the future under A1B scenario simulated by MIROC_Hires model," Theoretical and Applied Climatology, vol. 123, no. 3, pp. 461-471, 2016.

[10] Y. L. Luo, R. Yu, and X. Chen, "Investigation of the predictability and physical mechanisms of an extreme-rainfall- producing mesoscale convective system along the Meiyu front in east China: an ensemble approach," Journal of Geophysical Research-atmospheres, vol. 20, no. 20, pp. 10593-10618, 2015.

[11] X. Y. Ma and Y. C. Zhang, "Numerical study of the impacts of urban expansion on Meiyu precipitation over Eastern China," Journal of Meteorological Research, vol. 29, no. 2, pp. 237-256, 2015.

[12] F. Ping, Z. Luo, X. Tang, and L. Hu, "A simulation of the merger of convective clouds in the torrential rainfalls associated with the Meiyu front," Meteorology and Atmospheric Physics, vol. 123, no. 1, pp. 51-65, 2014.

[13] E.-K. Seo and K.-M. Kim, "Precipitating cloud characteristics during Changma as seen in TRMM PR observations," Advances in Meteorology, vol. 2017, Article ID 8598594, 13 pages, 2017.

[14] H. Chen, R. Yu, J. Li, W. Yuan, and T. Zhou, "Why nocturnal long-duration rainfall presents an eastward-delayed diurnal phase of rainfall down the Yangtze River Valley," Journal of Climate, vol. 23, no. 4, pp. 905-917, 2010.

[15] W. Yuan, R. Yu, M. Zhang, W. Lin, H. Chen, and J. Li, "Regimes of diurnal variation of summer rainfall over subtropical east Asia," Journal of Climate, vol. 25, no. 9, pp. 3307-3320, 2012.

[16] T. Zhou, R. Yu, H. Chen, A. Dai, and Y. Pan, "Summer precipitation frequency, intensity, and diurnal cycle over China: a comparison of satellite data with rain gauge observation," Journal of Climate, vol. 21, no. 16, pp. 3997-4010, 2008.

[17] K. T. Sample and S. P. Xie, "Large-scale dynamics of the Meiyu-Baiu rainband: environmental forcing by the Westerly Jet," Journal of Climate, vol. 23, no. 1, pp. 113-134, 2010.

[18] K. Soto, A. Manda, Q. Moteki et al., "Influence of the Kuroshio on mesoscale convective systems in the Baiu frontal zone over the East China sea," Monthly Weather Review, vol. 144, no. 2, pp. 1017-1033, 2016.

[19] M. Zhang and D. L. Zhang, "Subkilometer simulation of a torrential-rain-producing mesoscale convective system in east China. Part I: model verification and convective organization," Monthly Weather Review, vol. 140, no. 1, pp. 184201, 2012.

[20] H. F. Shen, G. Q. Zhai, Y. Zhu, and Y. Xu, "Numerical study of a mesoscale vortex in the planetary boundary layer of the Meiyu front," Acta Meteorologica Sinica, vol. 26, no. 6, pp. 788-802, 2012.

[21] M. Nagata and Y. Ogura, "A modeling case study of interaction between heavy precipitation and a Low-Level Jet over Japan in the Baiu season," Monthly Weather Review, vol. 119, no. 6, pp. 1309-1336, 1991.

[22] S. C. Albers, J. A. McGinley, D. L. Birkenheuer, and J. R. Smart, "The Local Analysis and Prediction System (LAPS): analyses of clouds, precipitation, and temperature," Weather Forecasting, vol. 11, no. 3, pp. 273-287, 1996.

[23] J. A. McGinley, S. C. Albers, and P. A. Stamus, "Validation of a composite convective index as defined by a real-time local analysis system," Weather Forecasting, vol. 6, no. 3, pp. 337-356, 1991.

[24] D. Birkenheuer, "The effect of using digital satellite imagery in the LAPS moisture analysis," Weather Forecasting, vol. 14, no. 5, pp. 782-788, 1999.

[25] S. C. Albers, "The LAPS wind analysis," Weather and Forecasting, vol. 10, no. 2, pp. 342-352, 1995.

[26] C. A. Hiemstra, G. E. Liston, R. A. Pielke Sr., D. L. Birkenheuer, and S. C. Albers, "Comparing local analysis and prediction system (LAPS) assimilations with independent 
observations," Weather and Forecasting, vol. 21, no. 6, pp. 1024-1040, 2006.

[27] D. Conte, M. M. Miglietta, and V. Levizzani, "Analysis of instability indexes during the development of a Mediterranean tropical-like cyclone using MSG-SEVIRI products and the LAPS model," Atmospheric Research, vol. 101, no. 1-2, pp. 264-279, 2011.

[28] A. Tiesi, M. M. Miglietta, D. Conte et al., "Heavy rain forecasting by model initialization with LAPS: a case study," IEEE Journal of Selected Topics in Applied Earth Observations and Remote Sensing, vol. 9, no. 6, pp. 2619-2627, 2016.

[29] J. Barcons, A. Folch, A. S. Afif, and J. R. Miro, "Assimilation of surface AWS using 3DVAR and LAPS an their effects on short-term high-resolution weather forecasts," Atmospheric Research, vol. 156, pp. 160-173, 2015.

[30] H. Jiang, S. S. Albers, Y. Xie et al., "Real-time applications of the variational version of the local analysis and prediction system (vLAPS)," Bulletin American Meteorological Society, vol. 96, no. 12, pp. 2045-2057, 2015.

[31] H. L. Li, B. Zhang, and B. Chen, "Local analysis and prediction system (LAPS) and its localization," Meteorological Science and Technology, vol. 36, no. 1, pp. 20-24, 2008, in Chinese.

[32] H. L. Li, C. G. Cui, and Z. B. Wang, "A study on application of Doppler radar data in LAPS," Plateau Meteorology, vol. 28, no. 1, pp. 1-107, 2009, in Chinese.

[33] H. L. Li and X. D. Xu, "Application of a three-dimensional variational method for radar reflectivity data correction in a mudslide-inducing rainstorm simulation," Advance in Atmospheric Sciences, vol. 34, no. 4, pp. 469-481, 2017.

[34] E. Gregow, E. Saltikoff, S. Albers, and H. Hohti, "Precipitation accumulation analysis-assimilation of radar-gauge measurements and validation of different methods," Hydrology Earth System Sciences, vol. 17, no. 10, pp. 4109-4120, 2013.

[35] H. L. Li, X. D. Xu, Y. Hu, Y. J. Xiao, and Z. B. Wang, “Assimilation of Doppler radar data and its impact on prediction of a heavy Meiyu frontal rainfall event," Advances in Meteorology, vol. 2018, Article ID 9482014, 14 pages, 2018.

[36] S. Hu, S. Gu, X. Zhang, and H. Luo, "Automatic identification of storm cells using Doppler radars," Acta Meteorologica Sinica, vol. 21, pp. 353-365, 2007.

[37] Y. J. Xiao, Three-dimensional multiple-radar reflectivity mosaics and its application study, Ph.D. thesis, pp. 96-113, Nanjing University of Information Science \& Technology, Nanjing, China, 2007, in Chinese.

[38] Y. J. Xiao, Y. Wan, J. Wang, B. Wang, and Z. Wang, "Study of an automated Doppler radar velocity dealiasing algorithm," Plateau Meteorology, vol. 31, pp. 1119-1128, 2012, in Chinese. 

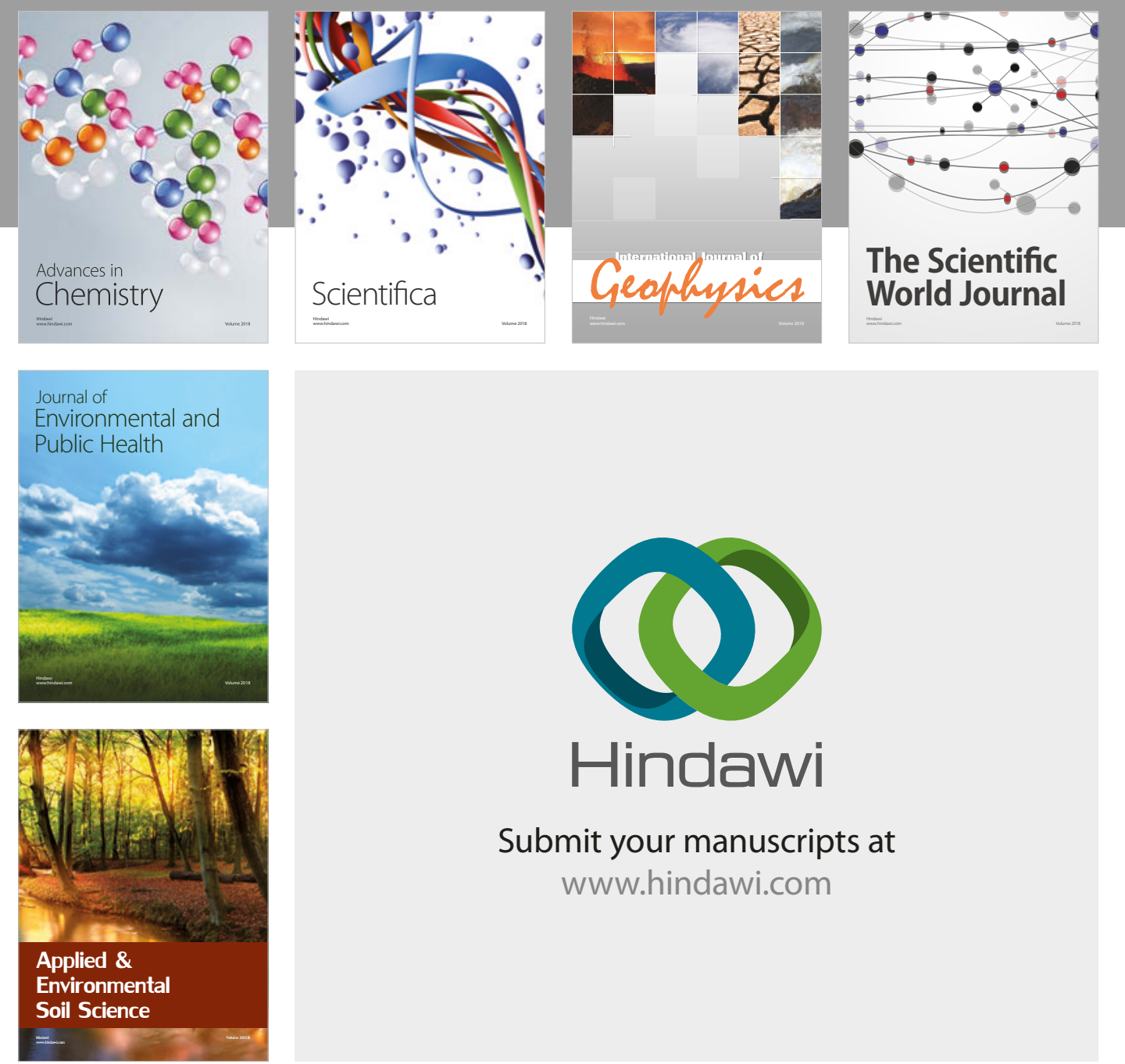

The Scientific

\section{World Journal}
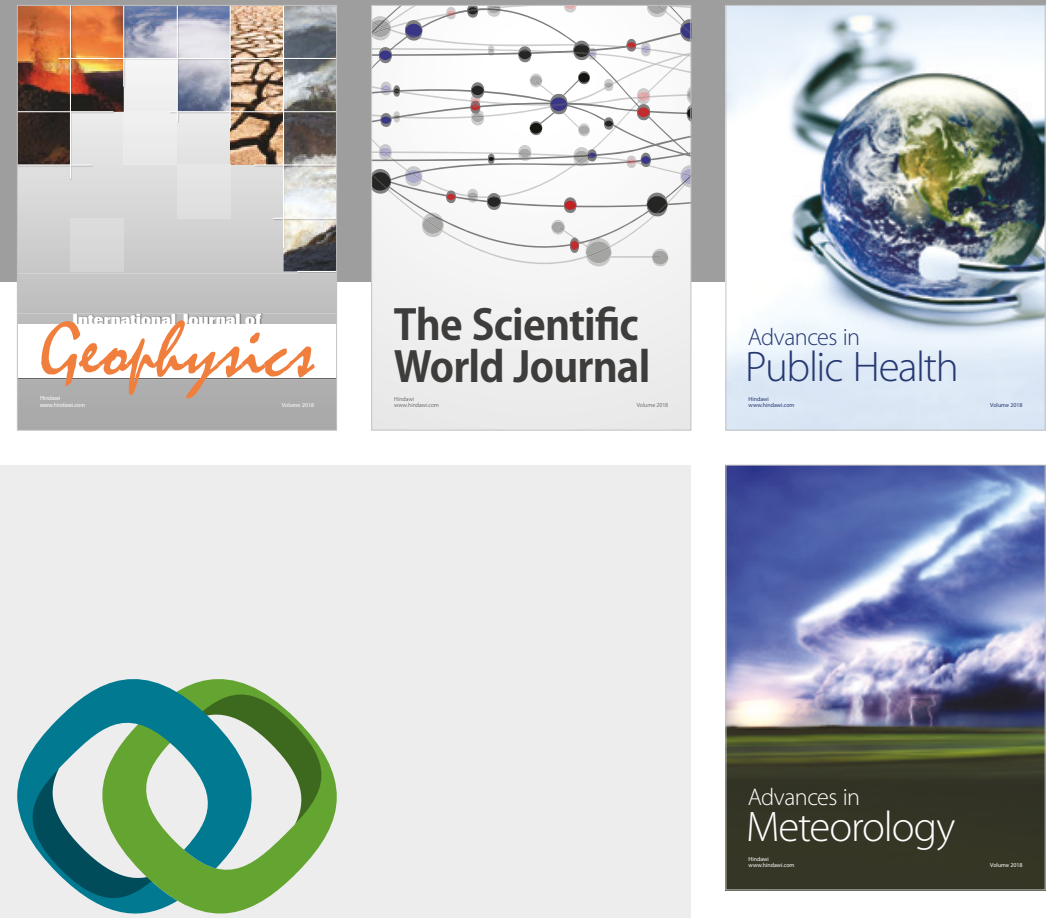

Advan

Public Health

\section{Hindawi}

Submit your manuscripts at

www.hindawi.com
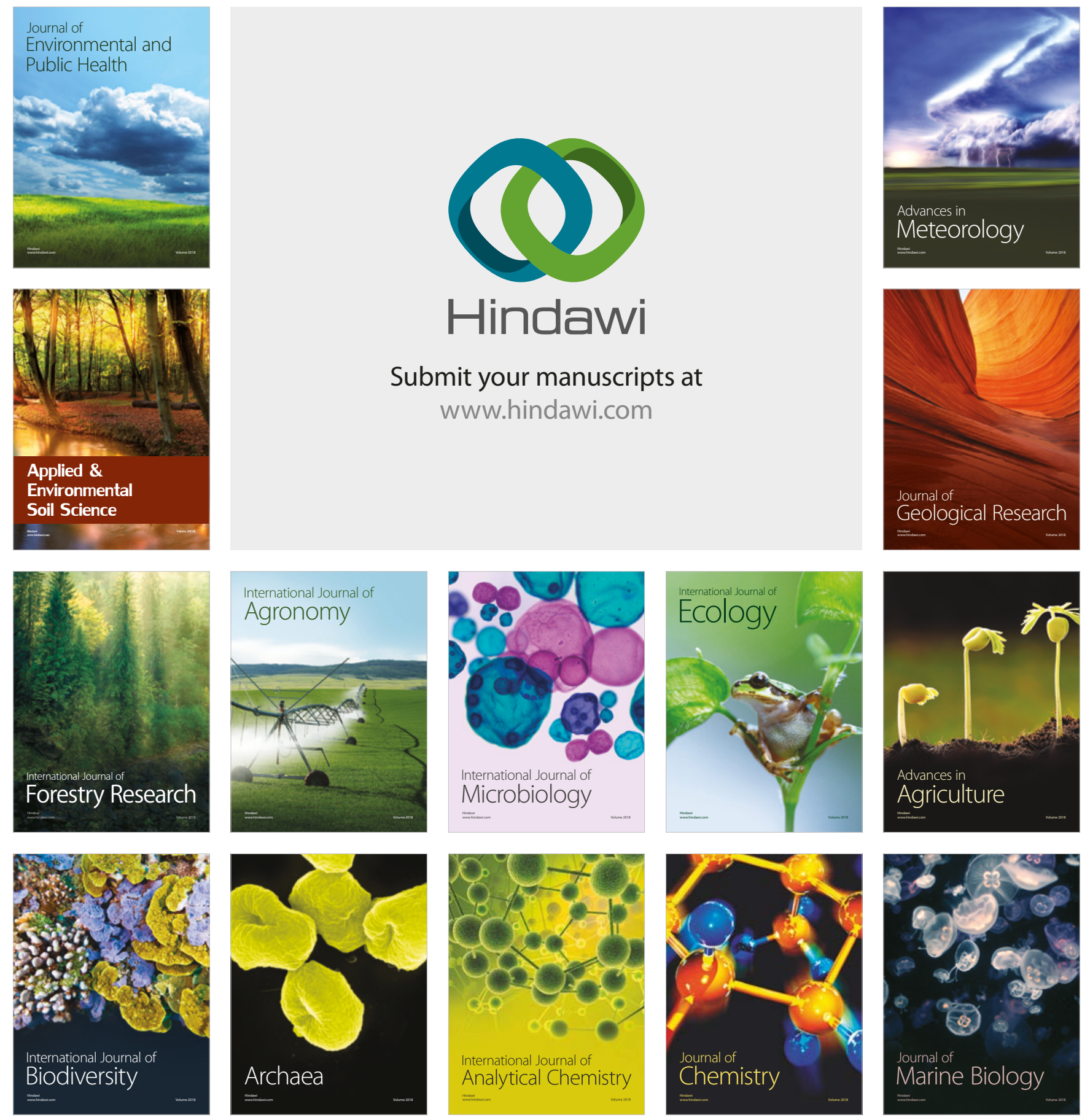